OPEN ACCESS

Edited by:

Daniel Wangpraseurt,

University of Cambridge,

United Kingdom

Reviewed by:

Ross Cunning,

Hawaii University, United States

Noga Stambler

Bar-Ilan University, Israel

*Correspondence:

Susana Enríquez

enriquez@cmarl.unam.mx susana.enriquezdominguez@

gmail.com

Specialty section:

This article was submitted to

Coral Reef Research,

a section of the journal

Frontiers in Marine Science

Received: 03 May 2017 Accepted: 08 September 2017 Published: 26 September 2017

Citation:

Scheufen T, Iglesias-Prieto $R$ and Enríquez $S$ (2017) Changes in the

Number of Symbionts and Symbiodinium Cell Pigmentation Modulate Differentially Coral Light

Absorption and Photosynthetic

Performance. Front. Mar. Sci. 4:309. doi: 10.3389/fmars.2017.00309

\section{Changes in the Number of Symbionts and Symbiodinium Cell Pigmentation Modulate Differentially Coral Light Absorption and Photosynthetic Performance}

\author{
Tim Scheufen ${ }^{1,2}$, Roberto Iglesias-Prieto ${ }^{1,3}$ and Susana Enríquez ${ }^{1 *}$ \\ 1 Unidad Académica de Sistemas Arrecifales Puerto Morelos, Universidad Nacional Autónoma de México, Cancun, Mexico, \\ ${ }^{2}$ Posgrado de Ciencias del Mar y Limnología of the Universidad Nacional Autónoma de México, Mexico City, Mexico, \\ ${ }^{3}$ Department of Biology, The Pennsylvania State University, University Park, PA, United States
}

In order to understand the contribution of pigmented coral tissues to the extraordinary optical properties of the coral-symbiont-skeleton unit, we analyzed the associations between structural and optical traits for four coral species, which broadly differ in skeleton morphology, tissue thickness and in the variation of coral pigmentation, symbiont content, Symbiodinium dominant type and Symbiodinium cell pigmentation (Ci). Significant differences among species were found for the maximum capacity of light absorption $\left(A_{\max }\right)$ and for the minimum pigmentation required to reach that maximum. The meandroid morphotype represented by Pseudodiploria strigosa showed a slightly lower $A_{\max }$ than the other three chalice-type species, while the thickest species, Montastraea cavernosa, required 2-3.5 times higher pigmentation to reach $A_{\max }$. In contrast, Orbicella faveolata and Orbicella annularis, which were able to harbor high number of symbionts and achieve the highest photosynthetic rates per area, showed the largest abilities for light collection at decreasing symbiont densities, leading to a more fragile photophysiological condition under light and heat-stress. Holobiont photosynthesis was more dependent on Symbiodinium performance in the less populated organisms. At reduced pigmentation, we observed a similar non-linear increase in holobiont light absorption efficiency ( $a^{*}$ Chla), which was differentially modulated by reductions in the number of symbionts and Symbiodinium Ci. For similar pigmentation, larger symbiont losses relative to $\mathrm{Ci}$ declines resulted in smaller increases in $\mathrm{a}^{*}$ Chla. Two additional optical traits were used to characterize light absorption efficiency of Symbiodinium ( $a^{*}$ sym $)$ and coral host $\left(a^{*} \mathrm{M}\right)$. Optimization of $a^{*}$ sym was well represented by $P$. strigosa, whereas $a^{*} \mathrm{M}$ was better optimized by $O$. annularis. The species with the largest symbiont content, $O$. faveolata, and with the thickest tissues, M. cavernosa, represented, respectively, less efficient solutions for both coral traits. Our comparison demonstrates the utility of optical traits to characterize inter-specific differences in coral acclimatization and performance. Furthermore, holobiont light absorption efficiency $\left(a^{*}\right.$ Chla $)$ appeared as a better proxy for the "bleached phenotype" 
than simple reductions in coral color. The analysis of a putative coordinated variation in the number of symbionts and in Symbiodinium cell pigmentation deserves special attention to understand holobiont optimization of energy collection ( $a^{*}$ Chla) and photosynthetic performance.

Keywords: light absorption, scleractinian coral, symbiont population, symbiont cell pigmentation, optical traits

\section{INTRODUCTION}

The maintenance of a healthy mutualistic endosymbiosis between a simple animal and an unicellular photoautotroph in the genus Symbiodinium is one of the cornerstones for the construction and maintenance of coral reefs. The solar energy that drives coral photosynthesis is collected by the photosynthetic apparatus of the symbionts and transformed efficiently into organic carbon. Photosynthates translocated to the host have been recognized as a major source of the energy that supports coral metabolism (Muscatine et al., 1981) and calcification rates (Pearse and Muscatine, 1971; Colombo-Pallotta et al., 2010). Therefore, any reduction in the production and translocation of photosynthates to the coral host will affect coral performance and growth. This places the photosynthetic activity of the symbionts at the center of the cellular processes that regulate coral performance. Furthermore, coral photosynthesis is directly affected by symbiosis instability under elevated temperatures (heat stress), but specially when this ancient and successful symbiosis collapses (coral bleaching). Therefore, coral bleaching not only results in severe losses in coral pigmentation and symbionts, but also in the generation of a dysfunctional holobiont. Such dysfunctional condition is expressed in a massive loss of symbionts and pigmentation (Weis, 2008), but also in the full suppression of coral photosynthesis (Scheufen et al., 2017). Anomalous seawater temperatures associated with global warming have been identified as the primary cause of mass coral bleaching events (Hoegh-Guldberg, 1999; Lesser and Farrell, 2004; Smith et al., 2005). Other environmental stressors like anomalous light increases, anomalous low temperatures, diseases, changes in salinity, etc., can also cause coral bleaching (i.e., Glynn, 1996; Lesser, 1996; Hoegh-Guldberg, 1999; Brown et al., 2000; Hoegh-Guldberg et al., 2005; Kemp et al., 2011).

Changes in coral pigmentation, however, are also related to seasonal variation in the number of symbionts (Fagoonee et al., 1999; Fitt et al., 2000) and/or in symbiont cell pigmentation (Brown et al., 1999; Fitt et al., 2000). Reductions in symbiont number are preferentially associated with increases in seawater temperature (e.g., Brown et al., 1999; Fagoonee et al., 1999; Fitt et al., 2000; Scheufen et al., 2017) while higher nutrient availability may better explain increases in symbiont density (Dubinsky et al., 1990; Stimson and Kinzie, 1991; Brown et al., 1999; Ferrier-Pagès et al., 2001). Reductions in coral pigmentation often occur during acclimation to high-light conditions (Falkowski and Dubinsky, 1981; Iglesias-Prieto and Trench, 1994; Hennige et al., 2009). Therefore, changes in coral pigmentation not only reflect symbiosis instability, but holobiont acclimatization to seasonal changes or variable environmental conditions.
The variability displayed by a single colony in the number of symbionts, in Symbiodinium cell pigmentation, and in the dominant symbiont type (Brown et al., 2000; Kemp et al., 2014) can be as large as inter-specific variation (Brown et al., 1999). However, although species that present low variation in the dominant Symbiodinium type, do display large changes in coral pigmentation and symbiont content, little attention has received the analysis of this variation and its functional meaning for coral performance. By contrast, a significant effort has been invested in the analysis of changes in the dominant symbiont type and coral susceptibility to bleach (e.g., Savage et al., 2002; Baker, 2004; Tchernov et al., 2004; Berkelmans and van Oppen, 2006; Kemp et al., 2006; Robison and Warner, 2006; Warner et al., 2006; Suggett et al., 2008; Fitt et al., 2009; Pettay et al., 2015). Interestingly, species that have shown low mortality rates during massive bleaching events, also had higher symbiont content per area (Stimson et al., 2002).

Changes in coral pigmentation directly affect the amount of solar energy absorbed by the symbiotic algae and potentially used in photosynthesis. Scleractinian corals have been recognized as one of the most efficient solar energy collectors (Enríquez et al., 2005) and users of this energy through photosynthesis (Rodríguez-Román et al., 2006), thanks to multiple scattering of light on coral carbonate skeletons. The extraordinary optical properties of scleractinian corals vary among skeleton morphologies (Terán et al., 2010; Marcelino et al., 2013; Enríquez et al., 2017), colony growth-forms (Anthony et al., 2005; Enríquez et al., 2017), coral pigmentation (Enríquez et al., 2005; Wangpraseurt et al., 2012), and differences among symbionts in their chlorophyll-specific absorption coefficient, $\mathrm{a}^{*}$ (Wyman et al., 1987; Dubinsky et al., 1990; Lesser et al., 2000; Stambler and Dubinsky, 2005; Hennige et al., 2009). However, our understanding of the association between changes in coral pigmentation and absorptance (i.e., fraction of incident light absorbed by the photosynthetic apparatus of Symbiodinium) is still insufficient. Only one study has documented so far this association for the species Porites branneri (Enríquez et al., 2005). In that study, the authors reported that the maximum capacity of light absorption of P. branneri $\left(\mathrm{A}_{\max }=\sim 93 \%\right)$ is already

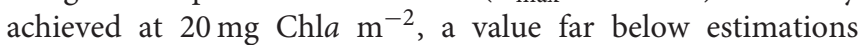
for terrestrial leaves (e.g., Carter and Knapp, 2001; Davis et al., 2011) and submerged macrophytes (Frost-Christensen and Sand-Jensen, 1992; Enríquez et al., 1994). How variable is the maximum capacity of light absorption (i.e., absorptance) among coral species, and how variable is the minimum amount of coral pigmentation required to reach that maximum, remains still uncertain.

The aim of this study was to contribute to fill this gap of knowledge through the characterization of the optical properties 
of four coral species, Orbicella annularis, Orbicella faveolata, Montastraea cavernosa, and Pseudodiploria strigosa, which widely differ in their skeleton morphology, tissue thickness and in the species plasticity for changing coral pigmentation, symbiont content, Symbiodinium dominant type and Symbiodinium cell pigmentation ( $\mathrm{Ci}$ ) and size (cell diameter). A second objective of this analysis was to elucidate potential differences between the number of symbionts (\# symbionts $\mathrm{cm}^{-2}$ ) and Symbiodinium pigmentation $\left(\mathrm{Ci}, \mathrm{pg} \mathrm{Chl} a \mathrm{sym}^{-1}\right)$, in their direct effects on holobiont optical properties. The data set analyzed corresponds to data from a recent study by Scheufen et al. (2017), who performed two experiments, one in March 2011 and the other in October 2011, and we also included unpublished data from a third experiment performed in June 2012 on the same four species and coral populations from the reef lagoon of Puerto Morelos (Mexican Caribbean). Scheufen et al. (2017) investigated differences in the thermal sensitivity of two seasonal coral phenotypes, winter and summer, of these four Caribbean species. Experimental corals were exposed to three temperature treatments (control, +2 and $+4^{\circ} \mathrm{C}$ ). The interest of the present comparison was also to test if changes in holobiont optical properties can contribute to explain the functional significance of the seasonal coral phenotypes documented by Scheufen et al. (2017). These authors reported for the winter coral condition, holobionts with reduced photosynthetic rates per area, per symbiont and per mass. In summer, however, corals generally increase their photosynthetic productivity and calcification rates
(Barnes and Lough, 1989; Scheufen et al., 2017), producing holobionts with reduced number of symbionts per area but more pigmented cells (Brown et al., 1999; Fitt et al., 2000; Scheufen et al., 2017). Thus, this comparison analyses variation among four coral species and two seasonal phenotypes in optical and structural traits, but also in gross photosynthesis, as well as changes associated with experimental exposures to heat-stress.

\section{MATERIALS AND METHODS}

\section{Skeleton Characteristics}

Coral skeleton macrostructure differs significantly among the four species (Figure 1), except for O. annularis and O. faveolata, which showed small but significant differences at micro-scale level, as O. faveolta has thinner septa (cf. Budd and Klaus, 2001). The three chalice-type species, M. cavernosa, O. faveolata, and O. annularis, present middle-sized corallites ( $<4$ and $<15 \mathrm{~mm}$ diameter), significantly smaller for both Orbicella spp. (Figure 1), and a slightly plocoid morphology with irregular presence of coenosteum. $P$. strigosa is the only species with a meandroid morphology, characterized by a distribution of septa as parallel lines running over the walls (Figure 1).

\section{Sample Collection}

The data-set analyzed was generated as part of a series of heat-stress experiments conducted during 2011 and 2012, to investigate the differential sensitivity of Caribbean coral reef
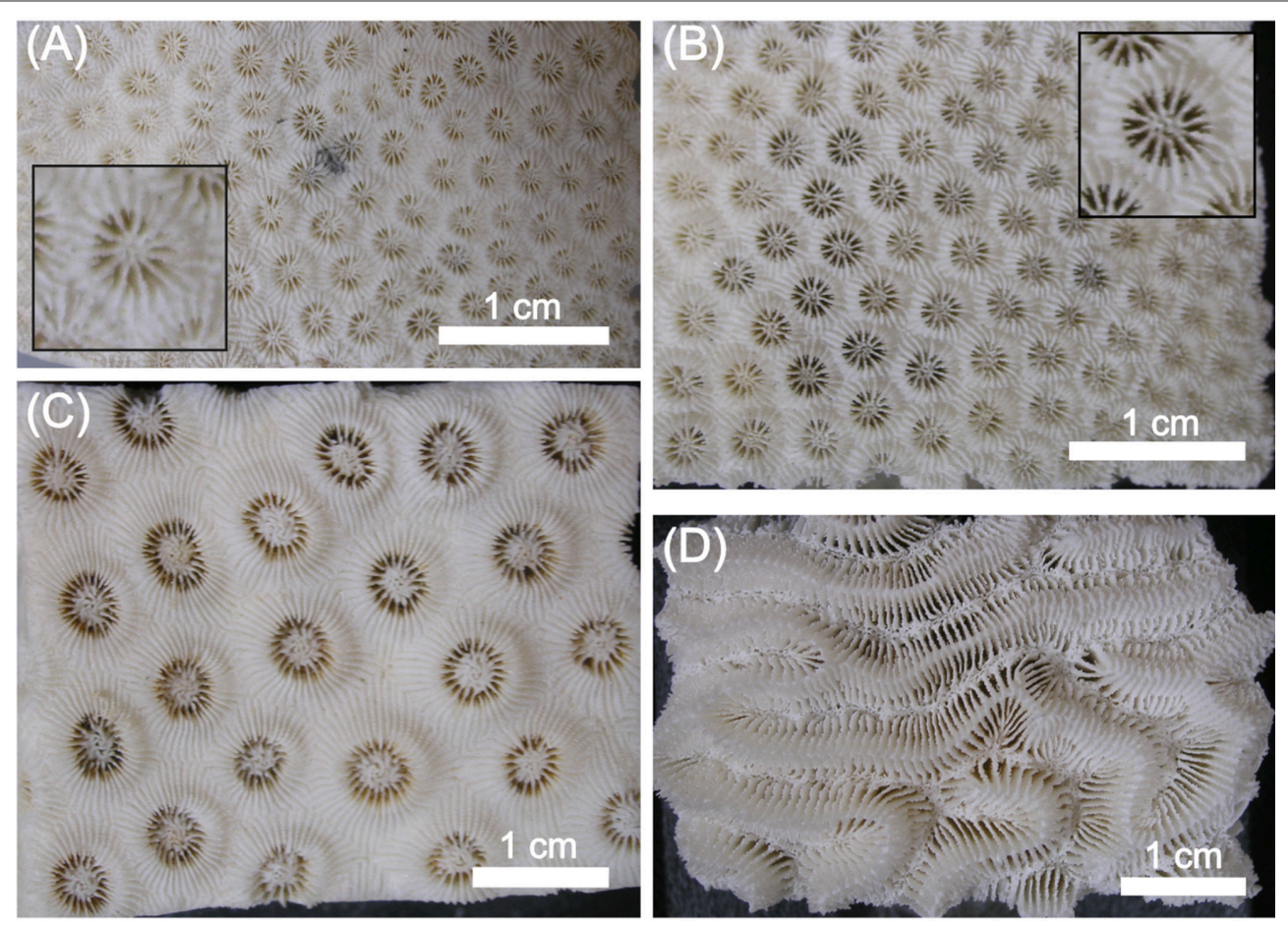

FIGURE 1 | Images of coral skeletons for (A) Orbicella annularis, (B) Orbicella faveolata, (C) Montastraea cavernosa, and (D) Pseudodiploria strigosa. The inserts in $(\mathbf{A}, \mathbf{B})$ show a close-up of the calyx structure of $O$. annularis and $O$. faveolata, respectively. The scale bar in each panel is $1 \mathrm{~cm}$. 
builders to global warming. The methodology employed for the determinations of the different parameters analyzed in this comparison, as well as for the experimental treatments that induced the variability investigated, is extensively described in Scheufen et al. (2017). See Supplementary Table 1 for number of samples of each parameter and species. Experimental organisms were obtained from three different colonies of $O$. annularis, O. faveolata, M. cavernosa, and P. strigosa collected by Scuba diving at a depth of $5 \mathrm{~m}$ in the same sites of the lagoon of Puerto Morelos (Mexico), on February 23rd and September 8th 2011, as well as on May 14th 2012. Coral pieces were cut into equally sized explants of ca. $10 \mathrm{~cm}^{2}$, and fixed to PVC plates using non-toxic underwater epoxy (Z-Spar Splash Zone, A788). These experimental nubbins were returned back to the reef lagoon for full recovery, where they were placed on tables at $5 \mathrm{~m}$ depth, located near the back-reef. After 15 days, the organisms were transported back to the UNAM mesocoms tank system, where they were distributed over three outdoor 152 $\mathrm{L}$ tanks equipped with running seawater. The temperature of the water was maintained at $28^{\circ} \mathrm{C}$ using commercial aquaria heaters (Process Technology, USA) located in the header tanks and connected to thermocouple sensors (J type, TEI Ingeniería, Mexico).

\section{Definition of the Different Coral Phenotypes Used in This Comparison}

Corals exposed to control conditions $\left(28^{\circ} \mathrm{C}\right)$ represent the "unstressed" phenotypes developed by the experimental organisms in the mesocosms facilities of the UNAM. These corals were collected at $5 \mathrm{~m}$ depth and at three different seasons (February, May, and September) in the reef lagoon of Puerto Morelos. Heat-stress was induced exposing corals to $30^{\circ} \mathrm{C}$ $\left(+2^{\circ} \mathrm{C}\right)$ and $32^{\circ} \mathrm{C}\left(+4^{\circ} \mathrm{C}\right)$. The maximum photochemical efficiency of photosystem II, $F_{v} / F_{m}$, was monitored daily at dusk using a diving PAM fluorometer (Heinz-Walz GmbH, Germany; see Scheufen et al., 2017 for details). As local $\mathrm{MMM}=30^{\circ} \mathrm{C}$, control corals exposed to $30^{\circ} \mathrm{C}$ in September did not experience any negative effect of the heat-stress treatment on $F_{v} / F_{m}$ (cf., Scheufen et al., 2017). Therefore, only when significant changes in $F_{v} / F_{m}$ were observed between control and heat-stressed samples, we considered that corals had expressed the "heatstressed" phenotypes. As concluded by Scheufen et al. (2017), only when the heat-stressed corals showed gross photosynthesis values not significantly different from 0 , we considered that corals had achieved the "bleached" phenotype.

\section{Chlorophyll $a$ and Symbiont Determinations}

Chlorophyll $a$ and symbiont extractions were performed by airbrushing coral samples with filtered seawater $(0.45 \mu \mathrm{m})$ and subsequent homogenization of coral tissue slurries with a tissue homogeniser (T 10 basic Ultra-Turrax, IKA). Symbiont samples were preserved adding $200 \mu \mathrm{l}$ of iodine (Lugol), until symbiont cells were counted in a hemocytometer. Pigment extraction was performed in acetone/dimethyl sulfoxide (95:5, vol/vol). For the calculation of the final chlorophyll $a$ density, we used the equations for dinoflagellates provided by Jeffrey and Humphrey (1975). Protein content was also estimated spectrophotometrically (Ocean Optics USB 4000 spectroradiometer, Ocean Optics Ltd, FL), using the equation of Whitaker and Granum (1980). Coral surface area was determined by covering the cleaned coral skeletons with aluminum foil following the method of Marsh (1970).

\section{Reflectance and Absorptance Determinations}

Coral reflectance (R) was measured according to Enríquez et al. (2005) and Vásquez-Elizondo et al. (2017). Samples were placed in a black container filled with filtered seawater and illuminated with homogeneous diffuse light. This illumination was provided from reflected light from a semi-sphere coated with barium oxide $(\mathrm{BaO})$ and placed above the sample and the black container. The semi-sphere was illuminated from below using a submersible LED ring placed around the coral sample inside the container, and enriched with halogen lamps and violetblue LEDs illumination. Both illumination enrichments allowed enhancing the light reflected by the semi-sphere in, respectively, red-infrared and violet-blue light. Reflected light was collected by placing a $2 \mathrm{~mm}$ diameter fiber-optics over the surface of the sample at an angle of $45^{\circ}$ and a distance of $1 \mathrm{~cm}$ from the coral surface. Measurements were performed between 400 and $750 \mathrm{~nm}$ using an Ocean Optics USB 4000 spectroradiometer (Ocean Optics Ltd, FL), averaging 10 scans per measurement with a boxcar width of $1.4 \mathrm{~nm}$ and a resolution of $0.2 \mathrm{~nm}$. For calibration, we used bleached coral skeletons of the respective species. Figures 2A-D shows reflectance spectra for each coral species together with the variability characterized for the unstressed, and for the stressed and bleached samples. Estimated absorbance spectra (Figures 2E-H) according to Shibata (1969) and Enríquez et al. (2005), were also calculated from reflectance data as $[\log (1 / R)]$. From these optical determinations, we estimated absorptance (A) for the chlorophyll $a$ peak at $675 \mathrm{~nm}$, as $\mathrm{A}_{675}=1-\mathrm{R}_{675}$, assuming that the amount of light transmitted (T) through the coral skeleton was negligible (Vásquez-Elizondo et al., 2017).

\section{Determinations of the Specific Absorption Coefficients}

The chlorophyll a specific absorption coefficient for the chlorophyll $a$ peak at $675 \mathrm{~nm}\left(\mathrm{a}^{*} \mathrm{Chl} a ; \mathrm{m}^{2} \mathrm{Chl} a^{-1}\right)$ was calculated according to Enríquez et al. (2005), using the following equation:

$$
a^{*} \mathrm{Chla}=(\mathrm{De} / \rho) \cdot \ln (10)
$$

Where De is the estimated absorbance value at $675 \mathrm{~nm}$, calculated as $\left[\mathrm{De}_{675}=\log \left(1 / \mathrm{R}_{675}\right)\right]$, and $\rho$ is the chlorophyll $a$ cross-section in $\mathrm{mg} \mathrm{Chl} a \mathrm{~m}^{-2}$. This parameter, $\mathrm{a}^{*} \mathrm{Chl} a$, is considered a descriptor of the pigment light absorption efficiency of the holobiont, as it combines changes in the photoacclimatory condition of Symbiodinium (cell pigmentation) in hospite, in the size of the symbiotic population, and in the dominant Symbiodinium type. In addition to this holobiont optical 

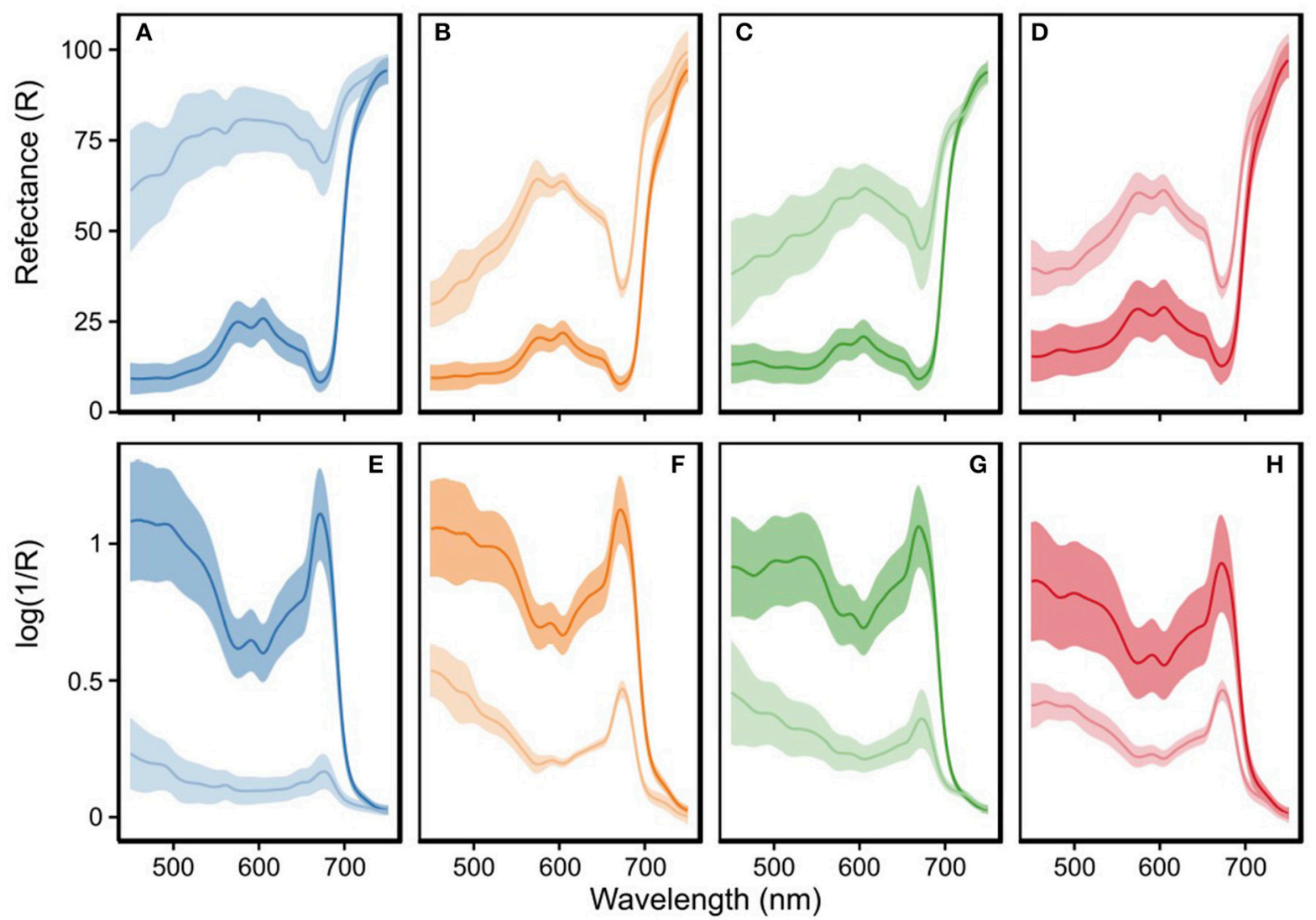

FIGURE 2 | Spectroscopic determinations for Orbicella annularis (blue), Orbicella faveolata (orange), Montastraea cavernosa (green), and Pseudodiploria strigosa (red) for unstressed (dark color) and stressed/bleached (light color) coral samples: (A-D) reflectance spectra and (E-H) calculated absorbance (D) spectra from reflectance (R) measurements as $\log (1 / \mathrm{R})$, according to Shibata (1969). Shading colored area represents the standard deviation (STD) variability for $>90$ determinations for unstressed samples of O. annularis ( $n=123)$, O. faveolata $(n=96)$, M. cavernosa $(n=110)$, and $P$. strigosa $(n=194)$; and $n>10$ for stressed/bleached samples of O. annularis $(n=122)$, O. faveolata $(n=13)$, M. cavernosa $(n=28)$, and $P$. strigosa $(n=54)$. Unstressed samples represent a subset of the $28^{\circ} \mathrm{C}$ treatment of all experiments, while for the stressed/bleached group data describe all samples characterized.

descriptor, two more specific absorption coefficients were estimated: the first named mass-specific absorption $\left(\mathrm{a}^{*} \mathrm{M}, \mathrm{m}^{2} \mathrm{mg}\right.$ protein $^{-1}$ ), allowed the quantification of the potential benefits returned to the host of the capacity of this symbiosis to collect solar energy; the second, symbiont-specific absorption $\left(\mathrm{a}^{*}{ }_{\text {sym }}, \mathrm{m}^{2} \mathrm{sym}^{-1}\right)$, allowed estimation of changes in the light absorption efficiency of Symbiodinium in hospite. For the calculation of the first descriptor we substituted $\rho$ by host protein content $\left(\mathrm{mg}\right.$ protein $\mathrm{cm}^{-2}$ ), whereas for the calculation of $\mathrm{a}^{*}$ sym we used symbiont density (\# sym $\mathrm{cm}^{-2}$ ). Briefly, $\mathrm{a}^{*}$ Chla was defined as a descriptor of holobiont light absorption efficiency; $\mathrm{a}^{*} \mathrm{M}$ describes host light absorption efficiency; and $\mathrm{a}^{*}$ sym the light absorption efficiency of Symbiodinium (see Table 1).

\section{Oxygen Evolution Determinations}

Oxygen fluxes were measured polarographically, using Clarktype $\mathrm{O}_{2}$ electrodes (Hansatech Instruments Ltd, Norfolk, UK) connected to a custom acrylic water-jacketed chambers (200 $\mathrm{ml})$ filled with filtered seawater $(0.45 \mu \mathrm{m})$. Coral samples were placed inside the chambers, and $\mathrm{NaHCO}_{3}(5 \mathrm{mM})$ was added to prevent $\mathrm{CO}_{2}$ limitation during incubations in small volume chambers (cf., Iglesias-Prieto et al., 1992; Enríquez et al., 2002; Cayabyab and Enríquez, 2007). The temperature within the water-jacketed chambers was maintained constant with an external water re-circulating bath equipped with a temperature control system (Model AD07R-20, PolyScience, Niles, IL). Five coral samples per species belonging to three different colonies, were used for each physiological determination. Maximum net photosynthesis (net $\mathrm{P}_{\max }$ ) was determined exposing the samples to a known saturation irradiance of $500 \mu \mathrm{mol}$ photons $\mathrm{m}^{-2} \mathrm{~s}^{-1}$ during $15 \mathrm{~min}$. The saturation irradiance was previously determined characterizing the photosynthesis response curve ( $\mathrm{P}$ vs. E) of each species. Oxygen evolution rates were measured again in darkness for five additional minutes to determine post-illumination respiration $\left(\mathrm{R}_{\mathrm{PI}}\right)$. Gross-photosynthesis $\left(\mathrm{P}_{\max }\right)$ was estimated by adding $\mathrm{O}_{2}$ consumption through respiration, to the previously 
TABLE 1 | Table of terms, definitions, and units for the structural, optical, and photosynthetic traits used in this comparison.

\begin{tabular}{|c|c|c|}
\hline Parameter & Definition & Units \\
\hline \multicolumn{3}{|c|}{ STRUCTURAL TRAITS } \\
\hline $\begin{array}{l}\text { Chlorophyll a } \\
\text { density }\end{array}$ & Chlorophyll a per area & mg Chla $\mathrm{m}^{-2}$ \\
\hline $\begin{array}{l}\text { Symbiont } \\
\text { density }\end{array}$ & Number of symbionts per area & $\times 10^{6} \#_{\text {sym } \mathrm{cm}^{-2}}$ \\
\hline $\mathrm{Ci}$ & Chlorophyll a per symbiont cell & pg Chla sym ${ }^{-1}$ \\
\hline $\begin{array}{l}\text { Soluble host } \\
\text { protein }\end{array}$ & Soluble host protein per area & $\mathrm{mg}$ protein $\mathrm{cm}^{-2}$ \\
\hline \multicolumn{3}{|c|}{ OPTICAL TRAITS (at 675 nm) } \\
\hline $\begin{array}{l}\text { Absorptance } \\
\text { (A) }\end{array}$ & Fraction of incident light absorbed & Dimensionless \\
\hline $\mathrm{a}^{*}$ Chla & $\begin{array}{l}\text { Chlorophyll a specific absorption } \\
\text { coefficient }\end{array}$ & $\mathrm{m}^{2} \mathrm{mg} \mathrm{Chla}-1$ \\
\hline$a_{\text {sym }}^{*}$ & $\begin{array}{l}\text { Symbiont specific absorption } \\
\text { coefficient }\end{array}$ & $\mathrm{m}^{2}$ sym $^{-1}$ \\
\hline$a^{\star} M$ & Protein specific absorption coefficient & $\mathrm{m}^{2} \mathrm{mg}$ protein $^{-1}$ \\
\hline \multicolumn{3}{|c|}{ PHOTOSYNTHETIC TRAITS } \\
\hline$P_{\max }$ & Gross-photosynthesis per area & $\mu \mathrm{mol} \mathrm{O} \mathrm{cm}^{-2} \mathrm{~h}^{-1}$ \\
\hline$P_{\text {sym }}$ & Gross-photosynthesis per symbiont & $\mathrm{pmol}_{2} \mathrm{sym}^{-1} \mathrm{~h}^{-1}$ \\
\hline$P_{M}$ & $\begin{array}{l}\text { Gross-photosynthesis per host } \\
\text { protein }\end{array}$ & $\mu \mathrm{mol} \mathrm{O}_{2}$ protein $^{-1} \mathrm{~h}^{-1}$ \\
\hline
\end{tabular}

determined net photosynthetic rates under saturation irradiance (net $\mathrm{P}_{\max }$ ).

\section{Data Analysis}

As mentioned above, the dataset analyzed represents pooled data from three heat-stress experiments. Supplementary Table 1 shows the number of samples per species and stress-level used in this comparative analysis. One-way ANOVA and Post-Hoc Tukey HSD tests allowed determination of significant differences among the unstressed samples, as well as the three different coral phenotypes investigated within each species (unstressed, stressed, and bleached). To analyse the association between absorptance and chlorophyll $a$ density, we used an asymptotic exponential function:

$$
\mathrm{y}=\mathrm{A}_{\max }\left(1-\mathrm{e}^{\left(-\mathrm{b}^{*} \text { Chl } a \text { density }\right)}\right)
$$

where $A_{\max }$ is the maximum absorptance reached and $\mathbf{b}$ is the exponential rise of the function.

Least-square regression analyses of $\log / \log$ transformed data $(\log \mathrm{y}=\log \mathrm{a}+\mathrm{b} \log \mathrm{x})$ were used to derive the allometric function: $\left[y=a^{*} x^{b}\right]$ between changes in the specific absorption coefficients ( $\mathrm{a}^{*} \mathrm{Chl} a, \mathrm{a}^{*} \mathrm{M}, \mathrm{a}^{*}{ }_{\text {sym }}$ ) and structural coral traits. Pearson correlation coefficients ( $r$ ) were used to describe the associations of variation between log-transformed parameters. Finally, principal component analysis (PCA) allowed exploring patterns at a multidimensional scale.

All analyses were conducted using $\mathrm{R}$ (Version 3.3.2; R Core Team, 2017) with the "car" (Fox and Weisberg, 2011), and "agricolae" (de Mendiburu, 2016) packages loaded.

\section{RESULTS}

\section{Structural and Functional Variability of the Un-stressed Samples}

For the unstressed corals, chlorophyll a density showed significant differences between the more pigmented (O. faveolata and $M$. cavernosa) and less pigmented (O. annularis) species (one-way ANOVA, Tukey HSD, $p<0.05$; Figure 3A). The coefficients of variation $(\mathrm{CV})$ were slightly higher for $P$. strigosa $(\mathrm{CV}=43 \%)$ relative to the values found for $O$. annularis $(\mathrm{CV}=29 \%)$, O. faveolata $(\mathrm{CV}=28 \%)$, and $M$. cavernosa $(\mathrm{CV}=28 \%)$. The highest symbiont densities (Figure 3B), and the lowest chlorophyll $a$ content per symbiont (Ci, Figure $3 \mathrm{C}$ ) were found for the two Orbicellas spp., while M. cavernosa and $P$. strigosa presented significantly lower symbiont density and higher Ci (one-way ANOVA, Tukey HSD, $p<0.05$ ). The species that showed the highest soluble host protein content was $M$. cavernosa $\left(6 \pm 0.7 \mathrm{mg}\right.$ protein $\left.\mathrm{cm}^{-2}\right)$, whereas $O$. annularis showed the lowest average value $\left(2.4 \pm 0.2 \mathrm{mg}\right.$ protein $\mathrm{cm}^{-2}$; Figure 3D). However, no significant differences were observed among O. annularis, O. faveolata, and P. strigosa for host protein content in the unstressed samples (one-way ANOVA, Tukey HSD, $p>0.05$ ).

Maximum photosynthetic rates per area $\left(\mathrm{P}_{\max }\right)$ were significantly higher in both Orbicella spp. (one-way ANOVA, Tukey HSD, $p<0.05$; Figure $3 F$ ), but symbiont contribution to holobiont photosynthetic production $\left(\mathrm{P}_{\text {sym }}\right)$ was the lowest (Figure 3G). $\mathrm{P}_{\text {sym }}$ showed a similar pattern of variation to $\mathrm{Ci}$ : the highest $\mathrm{P}_{\text {sym }}$ was observed in the unstressed samples of $P$. strigosa and $M$. cavernosa. These $\mathrm{P}_{\text {sym }}$ differences among species were however only significant for $P$. strigosa (one-way ANOVA, Tukey HSD, $p<0.05$; Figure 3G). Photosynthetic rates normalized to soluble protein content $\left(\mathrm{P}_{\mathrm{M}}\right)$ were highest for $O$. annularis and lowest for $M$. cavernosa (one-way ANOVA, Tukey HSD, $p<0.05$; Figure 3H).

With respect to the optical traits, unstressed samples of $O$. annularis, O. faveolata, and $M$. cavernosa showed equal maximum capacity for light absorption $\left(A_{\max }>90 \%\right)$. The lowest $\mathrm{A}_{\max }$ for the unstressed specimens was determined for P. strigosa $\left(\mathrm{A}_{\max }=88 \%\right.$; one-way ANOVA, Tukey HSD, $p<$ 0.05 , Figure 3I). All unstressed samples showed low values for chlorophyll $a$ specific absorption ( $\mathrm{a}^{*} \mathrm{Chl} a$; Figure 3J). The highest values were estimated for O. annularis (one-way ANOVA, Tukey HSD, $p<0.05$ ); which also showed the highest mass specific absorption ( ${ }^{*}{ }_{M}$; one-way ANOVA, Tukey HSD, $p<0.05$; Figure 3L). On the other hand, the highest symbiont specific absorption ( $\mathrm{a}^{*}{ }_{\text {sym }}$ ) was estimated for $M$. cavernosa and $P$. strigosa (one-way ANOVA, Tukey HSD, $p<0.05$; Figure 3K).

\section{Principal Component Analysis (PCA) for Non-stressed Holobionts}

Un-stressed samples of the four species investigated were clearly discriminated by PCA analysis (Table 2, Figure 4). The principal component 1 (PC1) was determined by four functional $\left(\mathrm{P}_{\mathrm{M}}\right.$, $\mathrm{P}_{\text {sym }}, \mathrm{a}^{*}{ }_{\mathrm{M}}, \mathrm{a}^{*}{ }_{\text {sym }}$ ) and three structural (symbiont density, $\mathrm{Ci}$, and protein content) traits, and explained 39\% of the variability (Table 2). This component was able to distinguish between the 

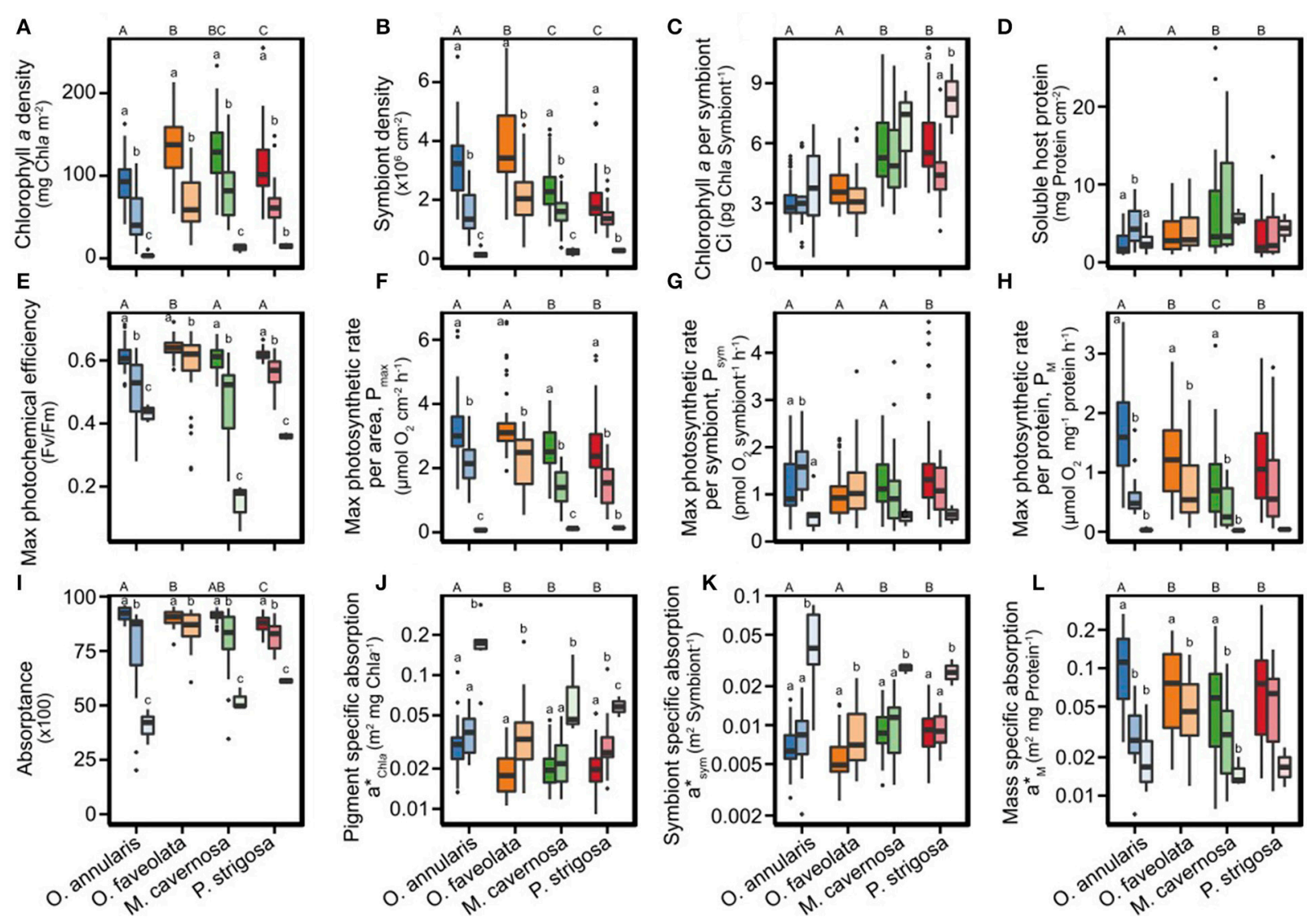

FIGURE 3 | Box plots of the variation of structural (A-D), photosynthetic (E-H), and optical (I-L) descriptors of the holobiont phenotype of Orbicella annularis (blue), Orbicella faveolata (orange), Montastraea cavernosa (green), and Pseudodiploria strigosa (red). Different shading describes the unstressed (dark), heat-stressed (light), and bleached phenotypes (lighter). Boxes encompass the 25 and $75 \%$ quartiles. The central line corresponds to the median, and bars extend to the 95 and $5 \%$ of the confidence limits. Uppercase letters indicate significant differences among species, while lowercase letters denote differences among coral phenotypes (ANOVA tests were performed across species using two-way ANOVA). The lack of lowercase letters indicate that changes were not significant.

two species that harbored higher number of symbionts, both Orbicellas spp., and the species with higher host protein content and Symbiodinium Ci, P. strigosa and M. cavernosa. The second component (PC2) diferentiated between the more pigmented (O. faveolata and M. cavernosa) and the less pigmented species (O. annularis and P. strigosa). This component increased the variability explained to $66 \%$, thanks to the contribution of changes in holobiont pigmentation (Chla density) and holobiont light absorption efficiency ( $\mathrm{a}^{*} \mathrm{Chl}$ ), with smaller contributions of coral descriptors normalized to symbiont and mass (Table 2). No correlation was found between this component and holobiont photosynthetic production. Finally, a third component (PC3) increased the variability explained to $80 \%$, thanks to the contribution of $\mathrm{P}_{\max }$, Symbiodinium $\mathrm{Ci}$ and two optical descriptors, $\mathrm{a}^{*} \mathrm{M}$ and $\mathrm{a}^{*}{ }_{\text {sym }}$ (Table 2).

\section{Structural and Functional Variability of the Stressed Corals}

Exposure to heat-stress induced in the two Orbicellas and $M$. cavernosa significant chlorophyll $a(>90 \%)$ and symbiont
(>89\%) losses (one-way ANOVA, Tukey HSD, $p<0.001$; Figures 3A,B). $P$. strigosa showed smaller changes but this species also reduced significantly its chlorophyll $a$ and symbiont number when compared with the unstressed samples (one-way ANOVA, Tukey HSD, $p<0.001$ ). No significant change was observed for Symbiodinium $\mathrm{Ci}$ in samples of $O$. annularis, O. faveolata, and $M$. cavernosa exposed to heatstress. Unexpectly, in $P$. strigosa we found a reduction in Symbiodinium $\mathrm{Ci}$ in the heat-stressed samples, but not in the bleached ones, which showed the highest values (one-way ANOVA, Tukey HSD, $p<0.001$; Figure 3C). Host soluble protein content did not present significant changes in the stressed samples of O. faveolata, M. cavernosa, and P. strigosa, while it increased significantly in O. annularis (Figure 3D).

$F_{v} / F_{m}$ and holobiont gross photosynthesis declined in all samples that suffered heat-stress (Figures 3E-H). $F_{v} / F_{m}$ reductions were largest for $M$. cavernosa (77\%), intermediate for $P$. strigosa and O. annularis (30-40\%) and lowest for O. faveolata (Figure 3E). Only three species, O. annularis, M. cavernosa, and $P$. strigosa, showed $\mathrm{P}_{\max }$ and $\mathrm{P}_{\mathrm{M}}$ values no significantly different to 0 for some of the samples exposed to heat-stress 
TABLE 2 | PCA analysis for the structural, optical, and photo-physiological coral descriptors of the un-stressed samples of Orbicella annularis, O. faveolata, Montastraea cavernosa, and Pseudodiploria strigosa.

\begin{tabular}{|c|c|c|c|}
\hline & PC1 & PC2 & PC3 \\
\hline Chlorophyll a (mg Chla m²) & 0.14 & -0.52 & 0.05 \\
\hline Symbionts (x10 $0^{6}$ sym cm ${ }^{-2}$ ) & 0.43 & -0.19 & -0.25 \\
\hline Ci (pg Chla sym-1) & -0.33 & -0.23 & 0.40 \\
\hline Soluble host protein $\left(\mathrm{mg} \mathrm{cm}^{-2}\right)$ & -0.35 & -0.26 & -0.14 \\
\hline $\mathrm{a}^{*}$ Chla $\left(\mathrm{m}^{2} \mathrm{mg} \mathrm{Chla}{ }^{-1}\right)$ & -0.07 & 0.52 & -0.03 \\
\hline$a^{*} \operatorname{sym}\left(m^{2}\right.$ sym $\left.^{-1}\right)$ & -0.41 & 0.21 & 0.29 \\
\hline$a^{*} M\left(m^{2}\right.$ mg protein $\left.{ }^{-1}\right)$ & 0.36 & 0.28 & 0.34 \\
\hline$P_{\max }\left(\mu \mathrm{mol} \mathrm{O}_{2} \mathrm{~cm}^{-2} \mathrm{~h}^{-1}\right)$ & -0.09 & 0.11 & -0.70 \\
\hline $\mathrm{P}_{\text {sym }}\left(\mathrm{pmol} \mathrm{O}_{2} \mathrm{sym}^{-1} \mathrm{~h}^{-1}\right)$ & -0.39 & 0.23 & -0.23 \\
\hline $\mathrm{P}_{\mathrm{M}}\left(\mu \mathrm{mol} \mathrm{O}_{2}\right.$ protein $\left.^{-1} \mathrm{~h}^{-1}\right)$ & 0.33 & 0.34 & 0.10 \\
\hline Standard deviation & 1.96 & 1.63 & 1.21 \\
\hline Proportion of variance & 0.39 & 0.27 & 0.15 \\
\hline Cumulative proportion & 0.39 & 0.65 & 0.80 \\
\hline
\end{tabular}

Bold values highlight strong correlations [loading $>0.3$ ] between original variables and PCs. The table shows the correlation values of each coral trait for the first three principal components. The table also shows the cumulative variation accounted for each component.

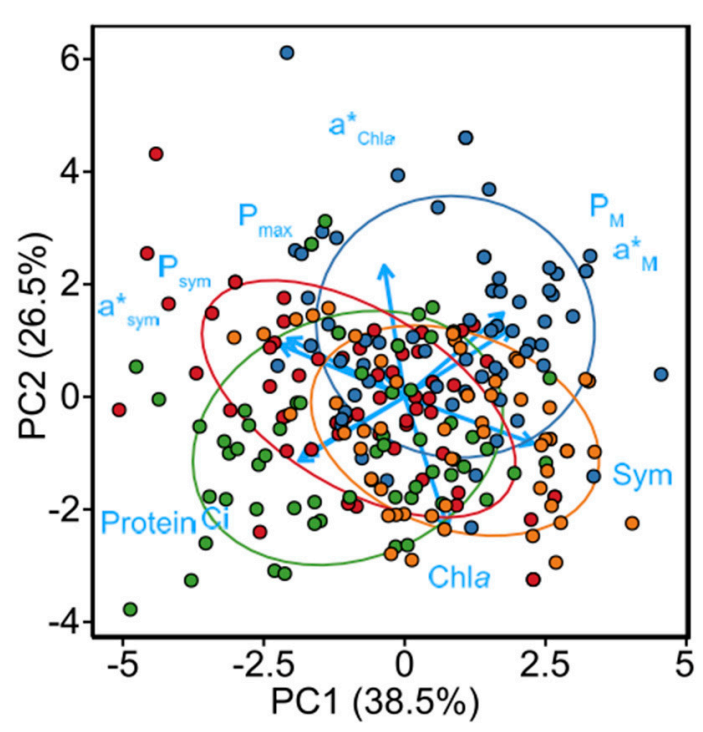

FIGURE 4 | Principal component analysis (PCA) plot showing the grouping of the unstressed specimens of Orbicella annularis (blue), Orbicella faveolata (orange), Montastraea cavernosa (green), and Pseudodiploria strigosa (red), based on the structural (chlorophyll a, symbiont, Ci, protein content), optical $\left(a^{*}\right.$ Chla,$a^{\star}$ sym, $\left.a^{*} M\right)$ and photosynthetic $\left(P_{\max }, P_{\text {sym }}, P_{M}\right)$ descriptors. Blue arrows indicate the correlation of the different parameters with PC1 and PC2.

(Figures 3F,H). We considered that these samples had reached the bleached phenotype, according to Scheufen et al. (2017), as these holobiont were fully dysfunctional with respect to photosynthesis. The only species that did not develop the bleached phenotype was $O$. faveolata, although some stressed specimens showed highly reduced $F_{v} / F_{m}$ values (Figure 3E), but still mantained significant photosynthetic activity. Symbiodinium photosynthetic rates $\left(\mathrm{P}_{\text {sym }}\right)$ were also significantly reduced in the bleached phenotypes (Figure 3G).

\section{Association of Variation between Coral Pigmentation and Optical Traits}

The declines observed in chlorophyll $a$ and symbiont density in the stressed organisms, induced significant reductions in coral absorptance (Figure 3I) together with large increases in the specific absorption coefficients ( $\mathrm{a}^{*} \mathrm{Chla}$ and $\mathrm{a}^{*}$ sym, Figures 3J,K). The greatest reductions in absorptance (55\%) were estimated for $O$. annularis, while $M$. cavernosa and $P$. strigosa experienced losses of, respectively, 43 and 30\% (one-way ANOVA, Tukey HSD, $p<0.001)$. O. faveolata was the species that showed the smallest declines in absorptance (7\%; one-way ANOVA, Tukey HSD, $p<0.001)$. Only a few stressed samples experienced large reductions in absorptance $(\sim 50 \%)$, but these holobionts still maintained significant photosynthetic activity $\left(\mathrm{P}_{\max }=0.7 \pm\right.$ $0.15)$. In addition to absorptance, the most prominent changes in the specific absorption coefficients were observed in O. annularis, followed by $P$. strigosa, and $M$. cavernosa, whereas $O$. faveolata showed the smallest variation in $\mathrm{a}^{*} \mathrm{Chla}$ and $\mathrm{a}^{*}$ sym (Figures 3J,K). Bleached organisms for all species showed the highest values for $\mathrm{a}^{*}{ }_{\mathrm{Chla}}$ and $\mathrm{a}^{*}{ }_{\text {sym }}$ and the lowest for $\mathrm{a}^{*}{ }_{\mathrm{M}}$ (Figures 3J-H).

\section{Principal Component Analysis (PCA) of the Heat-Stressed Corals}

The three main coral phenotypes, unstressed, stressed and bleached, were clearly grouped in a second PCA analysis, performed using exclusively coral functional descriptors (Table 3, Figure 5). The previous structural and functional differences became smaller in comparison with the variability generated by heat-stress. The principal component 1 (PC1) explained $39 \%$ of this variability thanks to $\mathrm{P}_{\mathrm{M}}, \mathrm{a}^{*}{ }_{\mathrm{M}}$, and $\mathrm{P}_{\max }$, which were negatively associated with $\mathrm{a}^{*} \mathrm{Chla} \mathrm{a}^{*}$ sym. The second component 2 (PC2), which increased the variability explained to $66 \%$, was mainly determined by $\mathrm{P}_{\text {sym }}$ and $\mathrm{P}_{\max }$ (Table 3 ). Accordingly, the dramatic reduction in coral photosynthesis induced by heat-stress, which was reflected in the holobiont rates $\left(\mathrm{P}_{\max }\right)$, in Symbiodinium photosynthesis $\left(\mathrm{P}_{\text {sym }}\right)$, and in the relative contribution of coral photosynthesis to the host $\left(\mathrm{P}_{\mathrm{M}}\right)$, was paired with large increases in the efficiency of solar energy collection of the holobiont $\left(\mathrm{a}^{*} \mathrm{Chl} a\right)$ and Symbiodinium $\left(\mathrm{a}^{*}{ }_{\text {sym }}\right)$. However, light absorption efficiency of the host $\left(a^{*} \mathrm{M}\right)$ was positively associated with holobiont photosynthesis (Figure 5, Table 3).

\section{Variation of Holobiont Optical Properties}

Optical traits ( $\mathrm{a}^{*} \mathrm{Chl} a, \mathrm{a}^{*}{ }_{\text {sym }}, \mathrm{a}^{*} \mathrm{M}$ ) showed: (i) a positive association between $\mathrm{a}^{*} \mathrm{Chl} a$ and $\mathrm{a}^{*}{ }_{\text {sym; }}$ (ii) a negative association between $\mathrm{a}^{*}$ sym and $\mathrm{a}^{*} \mathrm{M}$; and (iii) no association between $\mathrm{a}^{*} \mathrm{Chla}$ and $\mathrm{a}^{*}{ }_{\mathrm{M}}$ (Table 4). Strong correlations were also found between optical and structural coral traits (Table 4), as absorptance and the specific absorption coefficients were positively associated with increases in chlorophyll $a$, symbiont density, and Ci (Table 4). A negative colinearity was detected between symbiont density and Ci (Pearson $r=-0.29, p<0.001$; Table 4). This general pattern 
TABLE 3 | PCA analysis for the optical and photo-physiological coral descriptors of the un- stressed, stressed and bleached samples of Orbicella annularis,

O. faveolata, Montastraea cavernosa, and Pseudodiploria strigosa.

\begin{tabular}{lrrr}
\hline & PC1 & PC2 & PC3 \\
\hline $\mathrm{a}^{*}$ Chla $\left(\mathrm{m}^{2} \mathrm{mg} \mathrm{Chla}^{-1}\right)$ & $-\mathbf{0 . 3 7}$ & -0.18 & $\mathbf{0 . 5 6}$ \\
$\mathrm{a}^{*}$ sym $\left(\mathrm{m}^{2} \mathrm{sym}^{-1}\right)$ & $-\mathbf{0 . 4 6}$ & -0.05 & $\mathbf{0 . 4 9}$ \\
$\mathrm{a}^{\star} \mathrm{M}\left(\mathrm{m}^{2} \mathrm{mg} \mathrm{protein}^{-1}\right)$ & $\mathbf{0 . 4 9}$ & $\mathbf{0 . 3 6}$ & $\mathbf{0 . 3 7}$ \\
$\mathrm{P}_{\text {max }}\left(\mu \mathrm{mol} \mathrm{O}_{2} \mathrm{~cm}^{-2} \mathrm{~h}^{-1}\right)$ & $\mathbf{0 . 3 3}$ & $\mathbf{0 . 6 0}$ & 0.13 \\
$\mathrm{P}_{\text {sym }}\left(\mathrm{pmol} \mathrm{O}_{2}\right.$ sym $\left.^{-1} \mathrm{~h}^{-1}\right)$ & -0.07 & $\mathbf{0 . 6 8}$ & $\mathbf{0 . 3 4}$ \\
$\mathrm{P}_{\mathrm{M}}\left(\mu \mathrm{mol} \mathrm{O}_{2}\right.$ protein $\left.^{-1} \mathrm{~h}^{-1}\right)$ & $\mathbf{0 . 5 5}$ & -0.11 & $\mathbf{0 . 4 2}$ \\
Standard deviation & 1.54 & 1.25 & $\mathbf{1 . 1 4}$ \\
Proportion of variance & 0.39 & 0.26 & 0.22 \\
Cumulative proportion & 0.39 & 0.66 & 0.87 \\
\hline
\end{tabular}

Bold values highlight strong correlations [loading $>0.3$ ] between original variables and PCs. The table shows the correlation values of each coral trait for the first three principal components of this PCA analysis. The table also shows the cumulative variation accounted for each component.

presented some deviations when analyzing the variation within coral species (Supplementary Table 2), as symbiont density and $\mathrm{Ci}$ were not significantly correlated in O. annularis, O. faveolata, and $M$. cavernosa.

The associations of variation between absoptance and, both, chlorophyll $a$ and symbiont density (Figure 6) were described using the asymptotic function:

$$
\mathrm{A}=\mathrm{A}_{\max }\left(1-\mathrm{e}^{\left(-\mathrm{b}^{*} \text { Chl } a \text { density }\right)}\right)
$$

where $A_{\max }$ is the maximum absorptance value achieved at increasing pigmentation or symbiont density, and $\mathrm{b}$ describes the exponential rise of this association. This model allowed estimation for each coral species of the amount of chlorophyll $a$ and/or symbiont density required to reach $\mathrm{A}_{\max } O$. faveolata required the lowest pigmentation $\left(27 \mathrm{mg} \mathrm{Chl} a \mathrm{~m}^{-2}\right)$, followed by O. annularis ( $41 \mathrm{mg} \mathrm{Chl} \mathrm{m}^{-2}$ ), P. strigosa (41 mg Chla $\mathrm{m}^{-2}$ ),

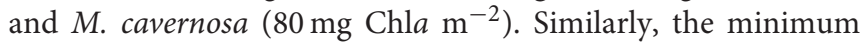
symbiont density required to reach that maximum was lowest for O. faveolata $\left(0.76 \times 10^{6} \#\right.$ cells $\left.\mathrm{cm}^{-2}\right)$ and $P$. strigosa $\left(0.92 \times 10^{6}\right.$ \# cells $\left.\mathrm{cm}^{-2}\right)$; and highest for $O$. annularis $\left(1.37 \times 10^{6} \#\right.$ cells $\left.\mathrm{cm}^{-2}\right)$ and $M$. cavernosa $\left(1.58 \times 10^{6}\right.$ symbionts $\mathrm{cm}^{-2}$; Figure 6).

A power function was used to describe the non-linear associations between the specific absorption coefficients and holobiont structural traits (Figures 6C,D; Supplementary Tables $3,4)$. Least-square regression analyses of $\log / \log$ transformed data according to the equation:

$$
\log (\mathrm{y})=\log (\mathrm{a})+\mathrm{b}^{*} \log (\mathrm{x})
$$

allowed estimation of the allometric morpho-functional associations, as: $\mathrm{y}=\mathrm{a} \mathrm{X}^{\mathrm{b}}$, where $\log (\mathrm{a})$ describes the intercept and $b$ the "scaling factor" of the allometric association or the linear slope of the log/log transformed data.

Two common models described the variation of $\mathrm{a}^{*} \mathrm{Chl} a$ as a function of changes in chlorophyll $a$ or symbiont density for all coral species investigated. The first model explained $75 \%$ of the variation examined in $\mathrm{a}^{*} \mathrm{Chl}$ :

$$
\begin{aligned}
& \log \mathrm{a}^{*} \mathrm{Chl} a\left(\mathrm{~m}^{2} \mathrm{mg}^{-1} \mathrm{Chl} a\right)=
\end{aligned}
$$

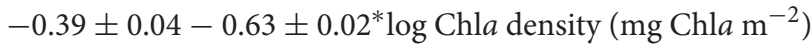

$$
\begin{aligned}
& \left(r^{2}=0.75, n=360, F=-1063.1, p<0.001\right) \quad \operatorname{Model}(1)
\end{aligned}
$$

The second was able to describe $35 \%$ of a ${ }^{*}$ Chla variation based on only changes in symbiont density:

$$
\begin{aligned}
& \log \mathrm{a}^{*} \mathrm{Chl} a\left(\mathrm{~m}^{2} \mathrm{mg}^{-1} \mathrm{Chl} a\right)= \\
& -1.47 \pm 0.04-0.45 \pm 0.03^{*} \log \text { symbiont density } \\
& \left(\times 10^{6} \# \mathrm{sym} \mathrm{cm}^{-2}\right) \\
& \left(r^{2}=0.35, n=360, F=195.03, p<0.001\right) \quad \operatorname{Model}(2)
\end{aligned}
$$

\section{Multiple Regression Analyses}

To better understand the dependence of coral optical traits (A and $\mathrm{a}^{*}{ }_{\text {chla }}$ ) on the variation of holobiont pigmentation, we performed multiple regression analyses in order to distinguish between direct and combined effects of changes in the number of symbionts (symbiont density) and in Symbiodinium pigmentation $(\mathrm{Ci})$ on this variation. The models found allow quantification of the effect of changes in the distribution of coral pigmentation on coral optics. According to these models:

(i) increases in symbiont density result in larger enhancements in coral absorptance than increases in Symbiodinium $\mathrm{Ci}$ :

$$
\begin{aligned}
\log \mathrm{A}=1.77 \pm 0.01+ & \mathbf{0 . 2 6} \pm 0.02^{*} \log \text { symbiont density } \\
& \left(\times 10^{6} \mathrm{~cm}^{-2}\right) \\
& +\mathbf{0 . 1 6} \pm 0.02^{*} \log \mathrm{Ci}\left(\mathrm{mg} \mathrm{Chla} \mathrm{cell}{ }^{-1}\right) \\
& -0.1 \pm 0.04^{*} \log \text { symbiont density }{ }^{*} \\
& \log \mathrm{Ci} \\
\left(R^{2}=0.57, n=360, F=\right. & 157.58, p<0.001) \quad \operatorname{Model}(3)
\end{aligned}
$$

and,

(ii) increases in Symbiodinium Ci result in larger reductions in pigment light absorption efficiency than increases in symbiont density:

$$
\begin{aligned}
& \log \mathrm{a}^{*} \mathrm{Chla}\left(\mathrm{m}^{2} \mathrm{mg} \mathrm{Chla}{ }^{-1}\right)= \\
& -0.97 \pm 0.02-\mathbf{0 . 4 8} \pm 0.05^{*} \log \operatorname{sym} \operatorname{density}\left(\times 10^{6} \#_{\operatorname{symcm}}{ }^{-2}\right) \\
& \mathbf{- 0 . 7 4} \pm 0.03^{*} \log \mathrm{Ci}\left(\mathrm{mg} \mathrm{Chla} \mathrm{cell}{ }^{-1}\right) \\
& -0.19 \pm 0.08^{*} \log \text { sym density* } \log \mathrm{Ci} \\
& \left(R^{2}=0.77, n=360, F=393.86, p<0.001\right) \quad \operatorname{Model}(4)
\end{aligned}
$$

Thus, holobionts that distribute their pigmentation over more symbionts at expenses of reducing Symbiodinium cell pigmentation will be able to collect more light (A) and more efficiently $\left(\mathrm{a}^{*} \mathrm{Chl} a\right)$ reducing holobiont pigment packaging. However, the significant interaction found for symbiont density and $\mathrm{Ci}$ in both models indicates that at increasing coral pigmentation the contribution of both parameters to enhance $\mathrm{A}$ or reduce $\mathrm{a}^{*} \mathrm{Chl} a$ is smaller. 

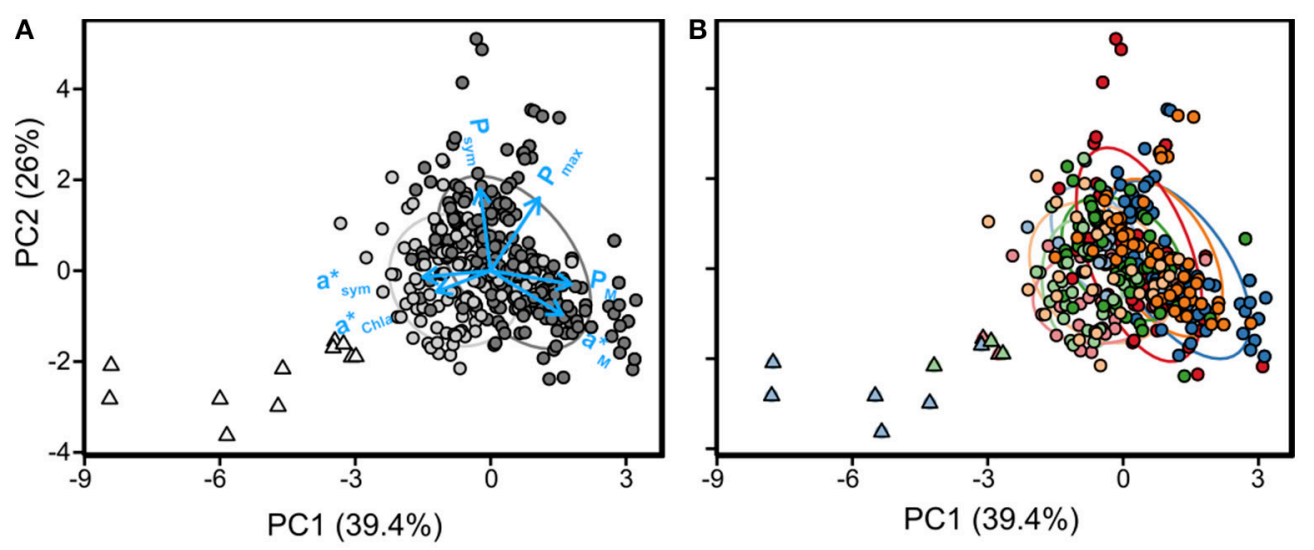

FIGURE 5 | Principal component analysis (PCA) plot showing (A) the grouping of samples in un-stressed (dark gray), stressed (gray), and bleached (light gray) coral phenotypes, based on the optical ( $a^{*}$ Chla,$a^{*}$ sym, $\left.a_{M}^{*}\right)$ and photo-physiological $\left(P_{\max }, P_{\text {sym }}, P_{M}\right)$ descriptors. Blue arrows indicate the correlation of the different descriptors with PC1 and PC2. Plot (B) described the same grouping identifying coral species with different color: Orbiella annularis in blue, Orbicella faveolata in orange, Montastraea cavernosa in green, and Pseudodiploria strigosa in red. Different shading describes coral phenotypes from unstressed (dark) to bleached (lighter).

TABLE 4 | Pearson correlation between optical, structural, and photo-physiological descriptors.

\begin{tabular}{|c|c|c|c|c|c|c|c|c|c|}
\hline & \multicolumn{4}{|c|}{ Optical } & \multicolumn{3}{|c|}{ Structural } & \multicolumn{2}{|c|}{ Photo-physiological } \\
\hline & $\log A$ & $\log a_{\text {chla }}^{*}$ & $\log a^{*}$ sym & $\log a_{M}^{*}$ & log Chla & log sym & $\log \mathbf{C i}$ & $\log P_{\max }$ & $\log P_{\text {sym }}$ \\
\hline \multicolumn{10}{|l|}{$\log A$} \\
\hline $\log a^{*}$ Chla & $-0.34^{\star \star \star}$ & & & & & & & & \\
\hline $\log a_{\text {sym }}^{*}$ & $-0.24^{\star \star \star}$ & $0.57^{\star \star \star}$ & & & & & & & \\
\hline $\log a_{M}^{*}$ & $0.38^{\star \star \star}$ & -0.08 & $-0.36^{\star \star \star}$ & & & & & & \\
\hline log Chla & $0.74^{\star \star \star}$ & $-0.87^{\star \star \star}$ & $-0.54^{\star \star \star}$ & $0.28^{\star \star \star}$ & & & & & \\
\hline log sym & $0.66^{\star \star \star}$ & $-0.59^{\star \star \star}$ & $-0.85^{\star \star \star}$ & $0.48^{\star \star \star}$ & $0.79^{\star \star \star}$ & & & & \\
\hline $\log \mathrm{Ci}$ & $0.14^{\star \star}$ & $-0.44^{\star \star \star}$ & $0.44^{\star \star \star}$ & $-0.30^{\star \star \star}$ & $0.35^{\star \star \star}$ & $-0.29^{\star \star \star}$ & & & \\
\hline $\log P_{\max }$ & $0.67^{\star \star \star}$ & $-0.44^{\star \star \star}$ & $-0.46^{\star \star \star}$ & $0.26^{\star \star \star}$ & $0.67^{\star \star \star}$ & $0.70^{\star \star \star}$ & -0.03 & & \\
\hline $\log P_{\text {sym }}$ & 0.1 & $0.14^{\star \star}$ & $0.43^{\star \star \star}$ & $-0.24^{\star \star \star}$ & -0.06 & $-0.28^{\star \star \star}$ & $0.32^{\star \star \star}$ & $0.49^{\star \star \star}$ & \\
\hline $\log P_{M}$ & $0.49^{\star \star \star}$ & $-0.28^{\star \star \star}$ & $-0.54^{\star \star \star}$ & $0.83^{\star \star \star}$ & $0.48^{\star \star \star}$ & $0.66^{\star \star \star}$ & $-0.28^{\star \star \star}$ & $0.70^{\star \star \star}$ & $0.14^{\star \star}$ \\
\hline
\end{tabular}

Significants levels: ${ }^{\star \star \star} 0.001 ;{ }^{\star \star} 0.01 ;{ }^{*} 0.05$.

Significant differences among species were also detected for these trends (Supplementary Tables 5, 6). For example, $O$. faveolata showed the largest scaling factor between $\mathrm{a}^{*} \mathrm{Chla}$ and chlorophyll $a$ density $(-0.89 \pm 0.04$, Supplementary Table 3), significantly larger than the smallest value estimated for $O$. annularis $(-0.5 \pm 0.03)$. These findings indicate that "pigment packaging" within coral tissues presents a relevant species-specific component that still needs to be characterized (Supplementary Tables 3, 4).

\section{Effects of Optical Traits on Holobiont Photosynthetic Rates}

PCA analyses and Pearson correlations highlighted significant colinearities between coral photosynthetic rates and optical descriptors (Tables 2-4, Figures 3-4). The optical trait better related to holobiont photosynthetic rates was $a^{*}{ }_{M}$, whereas $\mathrm{a}^{*} \mathrm{Chla}$ and $\mathrm{a}^{*}{ }_{\text {sym }}$ showed significant but negative associations with $\mathrm{P}_{\max }$ and $\mathrm{P}_{\mathrm{M}}$ (Table 4, Figure 4). Interestingly, increases in Symbiodinium light absorption efficiency ( $\mathrm{a}^{*}$ sym) were significantly and positively associated with symbiont contribution to holobiont photosynthetic production $\left(\mathrm{P}_{\text {sym }}\right)$. The three photosynthetic descriptors $\left(\mathrm{P}_{\max }, \mathrm{P}_{\text {sym }}\right.$, and $\left.\mathrm{P}_{\mathrm{M}}\right)$ were also positively related: a strong Pearson correlation was found between $\mathrm{P}_{\max }$ and $\mathrm{P}_{\mathrm{M}}$, and a significant association was also observed between $\mathrm{P}_{\max }$ and $\mathrm{P}_{\text {sym }}$ (Table 4).

\section{DISCUSSION}

This comparative characterization of the optical properties of scleractinian corals revealed that the three species with the chalice-type skeleton, $O$. annularis, $O$. faveolata, and M. cavernosa, were able to achieve higher maximum light absorption capacities $\left(A_{\max }>90 \%\right)$ than the species with the meandroid skeleton morphology, P. strigosa $\left(\mathrm{A}_{\max }=88 \%\right)$. This finding agrees with the results of a recent description of the variation of the optical properties of coral skeletons, where the meandroid morphotype was categorized as a skeleton with lower abilities to enhance multiple light scattering (Enríquez 


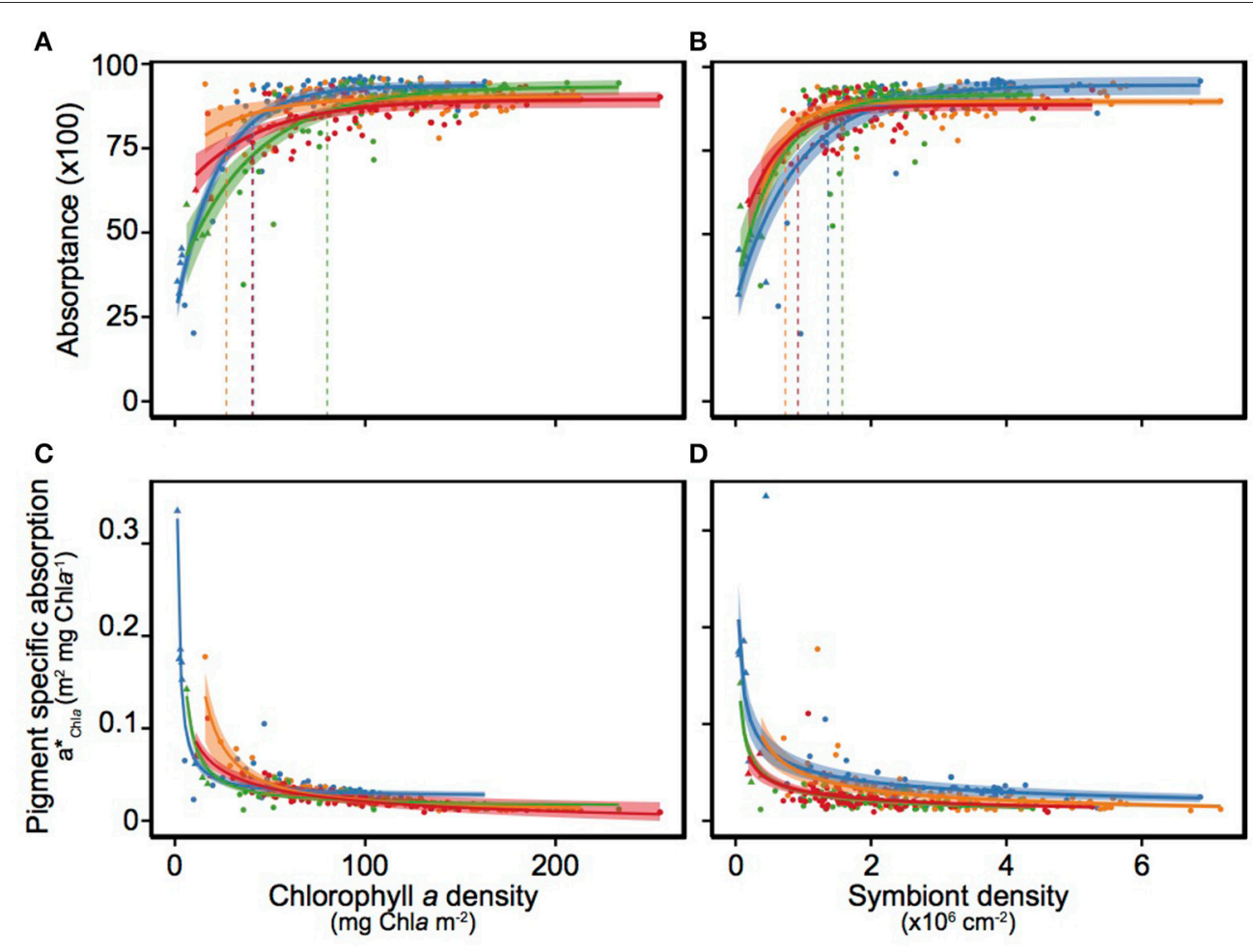

FIGURE 6 | Description of the variation of absorptance (A) and pigment specific absorption (a ${ }^{*}$ Chla) as a function of changes in chlorophyll a (A,C) and symbiont density (B,D), for Orbicella annularis (blue), Orbicella faveolata (orange), Montastraea cavernosa (green), and Pseudodiploria strigosa (red). Solid lines mark the asymptotic fits for each coral species and the shade area represents the extension of the 95 and $5 \%$ confident intervals. Discontinuous vertical color lines mark the values of chorophyll a or symbiont density where $A_{\max }$ was achieved for each species.

et al., 2017). The small although significant differences found for the maximum light absorption capacity of the holobiont were also reflected in large variation among species in the amount of pigmentation and/or symbionts required to achieve that maximum, $\mathrm{A}_{\max }$. O. faveolata was the species that showed the highest ability to maximize light absorption at the lowest pigmentation and symbiont densities. In contrast, $M$. cavernosa required the largest pigmentation to maximize light absorption but similar number of symbionts to O. annularis. Interestingly, despite the lower $\mathrm{A}_{\max }$ estimated for P. strigosa, this species was able to maximize absorptance with one of the lowest number of symbionts and holobiont pigmentation. According to these findings, this first comparison highlighted significant differences among coral species in holobiont capacity and efficiency to collect solar energy, either per unit of pigment or symbiont content. The inter-specific variability documented, however, still supports the extraordinary efficiency of scleractinian corals as solar energy collectors previously documented (Enríquez et al., 2005; Terán et al., 2010), as the amount of chlorophyll $a$ required to reach maximum absorptance was remarkably lower for three species ( $<50 \mathrm{mg} \mathrm{Chl} \mathrm{m} \mathrm{m}^{-2}$ ) if comparing with terrestrial leaves (>200 mg Chla $\mathrm{m}^{-2}$; see Carter and Knapp, 2001; Davis et al.,

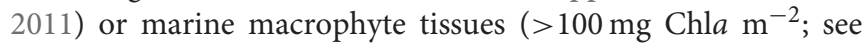
Frost-Christensen and Sand-Jensen, 1992; Enríquez et al., 1994). Previous characterizations for Stylophora pistillata, which did not consider the contribution of coral skeleton to the emergent optical properties of the coral-symbionts-skeleton unit, were also largely above (120 mg Chla m ${ }^{-2}$; see Dubinsky et al., 1984, 1990).

Our comparison also supports that "pigment packaging" (Duysens, 1956) still affects coral tissues. Non-linear reductions in light absorption efficiency, $\mathrm{a}^{*} \mathrm{Chl} a$, at increasing coral pigmentation per projected area (cross-section) were found for all species characterized, similarly to previous descriptions for multicellular structures (Enríquez and Sand-Jensen, 2003; Enríquez, 2005; Enríquez et al., 2005) and phytoplankton (e.g., Morel and Bricaud, 1981; Kirk, 2011). However, according to models 3 and 4, increases in symbiont density are more effective to counterbalance "pigment packaging" and enhance coral absorptance than increases in Symbiodinium cell pigmentation (Ci) in agreement with the results of Terán et al. (2010). These authors documented using Monte Carlo simulations of 2D skeleton models, that changes in the number of symbionts are more effective to collect light than changes in the absorptivity of Symbiodinium cells. Hence, the distribution of photosynthetic pigments over a higher number of symbionts results in larger enhancements in coral capacity (absorptance) and efficiency $\left(\mathrm{a}^{*}{ }_{\mathrm{Chl}} \mathrm{a}\right)$ of light absorption. On the other side, for similar coral pigmentation increases in Symbiodinium pigment content $(\mathrm{Ci})$ at the same time that the number of symbionts is reduced, leads to higher "pigment packaging" (lower a* $\mathrm{Chl} a$ ) within the 
coral-symbiont-skeleton unit. This coral structural adjustment produces a more inefficient holobiont to collect solar energy, but with perhaps functional advantages under increasing levels of light stress. Our comparative study also highlighted a speciesspecific component in that "pigment packaging," which needs still to be characterized. This component has to be related to the optical properties of coral skeletons, optical properties of Symbiodinium cells (i.e., cell diameter and pigment content, $\mathrm{Ci}$ ), coral tissue thickness, Symbiodinium distribution within coral tissue, and also species plasticity for changing symbiont content and Symbiodinium cell pigmentation (Ci). Among them, variation in the optical properties of coral skeleton, tissue thickness, and species plasticity for changing symbiont content and Symbiodinium cell pigmentation (Ci), are more likely the most important coral traits involved in the regulation of holobiont optical properties.

Seasonal changes in the number of symbionts and in Symbiodinium Ci (e.g., Brown et al., 1999; Fagoonee et al., 1999; Fitt et al., 2000) may express the optimization of holobiont optical properties to: (i) minimize pigment packaging under optimal conditions or decreasing light levels; or (ii) enhance photoprotection under increasing light stress. Therefore, we propose that the summer coral phenotype recently documented by Scheufen et al. (2017) characterized by increasing Symbiodinium $\mathrm{Ci}$ at the same time that the number of symbionts is reduced, may be the optimal holobiont adjustment to the seasonal increase in seawater temperature, in order to enhance the high-light photoprotective response of Symbiodinium in hospite. However, too large increases in Symbiodinium $\mathrm{Ci}$ at reduced number of symbionts may produce a more sensitive holobiont under high light and/or heat stress conditions, as small loses in the number of cells will lead to larger changes in coral pigmentation and thus, larger enhancements in $\mathrm{a}^{*} \mathrm{Chla}$ (Figure 7). The extremely high $\mathrm{a}^{*}$ values found for the bleached phenotype supports the relevance of this optical descriptor to determine a functional "tipping point" for this symbiosis, set when a* rises to levels unacceptable for maintaining symbiont photosynthesis due to extremely high local light fields for Symbiodinium. In contrast, winter increases in the number of symbionts may require reductions in Symbiodinium $\mathrm{Ci}$ to counterbalance pigment packaging and enhance the penetration of light into coral tissues to illuminate sufficiently the different symbiont layers. This adjustment would be particularly important for coral species with skeletons with reduced efficiency to enhance multiple light scattering (Enríquez et al., 2017). In the holobiont acclimatization to summer, however, the decrease in the number of symbionts would result in very efficient holobionts to collect solar energy (high $\mathrm{a}^{*} \mathrm{Chl}$ ) but with higher risk of reaching the bleached phenotype under light and/or heat stress, if such declines are not associated with increases in Symbiodinium $\mathrm{Ci}$ (Figure 7). According to this interpretation, the functional link between structural and optical coral traits could explain the effect of changes in the number of symbionts and/or Symbiodinium $\mathrm{Ci}$ on holobiont performance, irrespective of the occurrence or not of additional changes in the dominant Symbiodinium type, and thus, in the physiological response of the symbionts. In this study, we did not characterize these changes, but previous

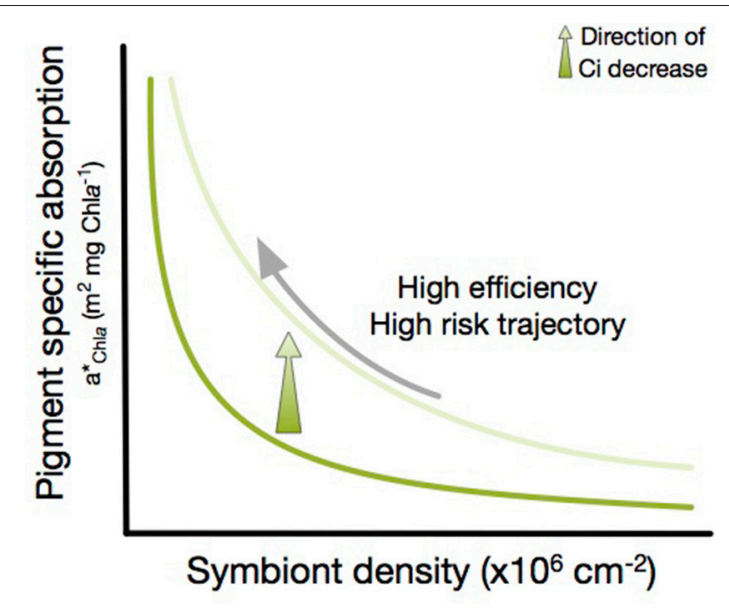

FIGURE 7 | Theoretical scheme of the modulating effect of Symbiodinium $\mathrm{Ci}$ on the association of $a^{*}$ Chla with changes in symbiont density. The lower (dark green) line shows the variation of $\mathrm{a}^{*} \mathrm{Chla}$ with a constant $\mathrm{Ci}$ calculated form the standard deviation above the mean $\mathrm{Ci}$ (high $\mathrm{Ci}$ condition). The upper (light green) line shows the variation with a constant $\mathrm{Ci}$ value calculated from the standard deviation below the mean $\mathrm{Ci}$. The green arrow indicates the direction of $\mathrm{a}^{*}$ Chla increases when a stable symbiont density decreases its $\mathrm{Ci}$. The upper trajectory leads to faster increase in $\mathrm{a}^{*}$ Chla, but also a higher risk of collection too much light under heat stress and suffering higher photo-damage. The real trajectories for each species can be found in Supplementary Figure 1.

descriptions of the variability of Symbiodinium dominant type for the four species investigated from the reef lagoon of Puerto Morelos (Mexico) have reported the presence of C3d (C3e) in $M$. cavernosa; $\mathrm{B} 1$ and $\mathrm{C} 1$ types in P. strigosa; and $\mathrm{C} 7$ and D1a/Symbiodinium trenchii in O. faveolata (LaJeunesse, 2002). A more detailed study by Kemp et al. (2015) on O. faveolata growing at the "Bocana" in the reef lagoon of Puerto Morelos, reported the presence of $\mathrm{A} 3, \mathrm{~B} 1, \mathrm{~B} 17, \mathrm{C} 17$, and $\mathrm{D} 1 \mathrm{a} / \mathrm{S}$. trenchii. With respect to O. annularis LaJeunesse (2002) documented the presence of $\mathrm{B} 1, \mathrm{C} 3$, and $\mathrm{D} 1 \mathrm{a} / \mathrm{S}$. trenchii in corals collected from reefs at Lee Stocking islands, in Bahamas. From our own previous analyses, we found $\mathrm{A} 3$ and $\mathrm{B} 1$ in O. annularis and A3, B17, C7, and D1a/S. trenchii in O. faveolata, in colonies growing at similar sites and depths to those analyzed in this study from the reef lagoon of Puerto Morelos (unpublished data). Such variability in the dominant Symbiodinium type could also help to explain part of the variation not accounted in this study for $\mathrm{a}^{*}$ and $\mathrm{P}_{\max }$.

\section{Structural and Functional Variability among Coral Species}

PCA was able to describe $80 \%$ of the inter-specific variability displayed by non-stressed holobionts (Figure 4), highlighting relevant association of variation between structural and functional traits. The first component (PC1) discriminated between the species with the ability to harbor high number of symbionts, the two Orbicellas, and P. strigosa and M. cavernosa, two species characterized by thick tissues (high host soluble protein content) and highly pigmented symbionts. The second component (PC2) distinguished between highly pigmented 
(O. faveolata and M. cavernosa) and less pigmented species (O. annularis and $P$. strigosa). Thus, the reduced host mass and high number of symbionts of the two Orbicellas allowed these species to achieve higher light absorption efficiency and photosynthetic production per mass $\left(\mathrm{a}^{*} \mathrm{M}\right.$ and $\left.\mathrm{P}_{\mathrm{M}}\right)$. Accordingly, the "evolutionary solution" represented by the two Orbicellas, but in particular by $O$. annularis characterized by low pigmented thin tissues, has produced holobionts with high efficiency for solar energy collection $\left(\mathrm{a}^{*} \mathrm{Chl} a\right)$ and high photosynthetic returns to the host $\left(\mathrm{P}_{\mathrm{M}}\right)$. The third component (PC3) of the PCA analysis accounted for the effect on holobiont photosynthetic production $\left(\mathrm{P}_{\max }\right)$ of the interspecific structural and optical variability analyzed in this study. This component showed that the most productive holobionts $\left(\mathrm{P}_{\max }\right)$ tend to present lower light absorption efficiencies for both symbiotic partners, host $\left(a^{*}{ }_{M}\right)$ and Symbiodinium $\left(\mathrm{a}^{*}{ }_{\text {sym }}\right)$, and harbor symbionts with lower Ci values (Table 2, Figure 4). All these associations of variation between structural and functional coral traits support the potential of this approach to understand differences among coral species in the advantages or constraints that these symbioses may provide to the holobiont and to each member of the mutualistic association, the animal and the alga. Furthermore, a trade-off between increases in the number of symbionts and reductions in Symbiodinium Ci may be inferred from this analysis. The first strategy requires higher light scattering abilities of coral skeleton (Enríquez et al., 2017) to offset the packaging effect, enhance the local light field of Symbiodinium and ensure higher benefits for the host $\left(\mathrm{P}_{\mathrm{M}}\right.$ and $\left.\mathrm{a}^{*} \mathrm{M}\right)$. In contrast, the ecological and/or evolutionary success of the second option would primarily depend on the capacity of Symbiodinium to maximize light collection efficiency $\left(\mathrm{a}^{*}{ }_{\text {sym }}\right)$ and its contribution to holobiont photosynthetic production $\left(\mathrm{P}_{\text {sym }}\right)$.

\section{Structural and Functional Variability among Coral Phenotypes}

In addition to these inter-specific differences, our comparison also revealed common changes among species for the heatstressed and bleached coral phenotypes. Indeed, PCA analysis allowed distinction between the bleached and the heat-stressed samples (Figure 5). Changes in holobiont photosynthesis $\left(\mathrm{P}_{\max }\right)$, positively associated with $\mathrm{a}^{*} \mathrm{M}$ and negatively with $\mathrm{a}^{*}{ }_{\text {sym }}$ and $\mathrm{a}^{*}$ Chla, were able to describe $40 \%$ of the variability contained in the whole data set (PC1). This finding supports previous conclusions by Scheufen et al. (2017), who documented that the bleached coral phenotype is determined by the full suppression of coral photosynthesis and large increases in the light absorption efficiency of Symbiodinium ( $\left.\mathrm{a}^{*}{ }_{\text {sym }}\right)$ and the holobiont $\left(\mathrm{a}^{*} \mathrm{Chl} a\right)$. We also found here that the un-stressed holobiont condition was better described by $\mathrm{a}^{*} \mathrm{M}$, which may quantify the efficiency of the symbiosis to return to the host the solar energy collected (Table 3). The second (PC2) and third (PC3) components, which increased the variability explained to 66 and $87 \%$, respectively, discriminated between two un-stressed holobionts: one that favors enhancing the photosynthetic contribution of Symbiodinium to holobiont production $\left(\mathrm{P}_{\text {sym }}\right)$; and a second strategy that favors enhancing the benefits for the host $\left(\mathrm{P}_{\mathrm{M}}\right.$ and $\left.a^{*}{ }_{M}\right)$. According to this, PC1 described the evolution of the stressed phenotype of all species toward a common bleached condition; whereas PC2 and PC3 allowed distinction among un-stressed species and/or seasonal phenotypes.

Another conclusion of this analysis in agreement with Scheufen et al. (2017), is that reductions in coral pigmentation are insufficient to define the bleached coral phenotype. Yet, other holobiont descriptors in addition to coral color are needed to determine the dysfunctional condition of these ancient symbioses. Coral photosynthetic rates appeared as the strongest descriptors, but our study supports the capacity of optical traits to recognize a bleached coral (Figure 3). Severe reductions in coral absorptance (A), but also dramatic increases in light absorption efficiency of chlorophyll $a\left(\mathrm{a}^{*}{ }_{\mathrm{chl} a}\right)$ and light absorption efficiency of Symbiodinium ( $\mathrm{a}^{*}{ }_{\text {sym }}$ ) can be used to differentiate an stressed coral from a dysfunctional symbiosis. More work is, however, needed to fully understand the natural variability displayed by coral optical traits and its relation to holobiont performance and colonial growth.

Micro-scale approaches are useful tools for the characterization of the internal light fields of the symbionts (Kühl et al., 1995; Wangpraseurt et al., 2012, 2014, 2016; Brodersen et al., 2014). This approach has documented the presence of light gradients (Wangpraseurt et al., 2012) and lateral light transfer within coral tissues (Wangpraseurt et al., 2014), which apparently are more pronounced in corals with thicker tissues. Optical characterizations of coral skeletons (e.g., Enríquez et al., 2005, 2017; Terán et al., 2010; Marcelino et al., 2013) are also fundamental to understand the direct contribution of the skeleton to modify the internal light field of Symbiodinium. In addition to these approaches, the understanding of the optical properties of the whole coral-alga-skeleton unit cannot be overlooked, as it is central to recognize differences among species and phenotypes in coral performance and competitive abilities. Our analysis is a first attempt to investigate this potential, analyzing the optical properties for four coral species. Further research is still needed to characterize the diversity of structural and functional solutions achieved by these ancient symbioses along their evolutionary history, and the utility of optical coral traits for the development of the coral Trait-based approach proposed by Madin et al. (2016).

\section{AUTHOR CONTRIBUTIONS}

SE and RI designed research, TS performed research, TS and SE analyzed data and wrote the paper. All authors contributed to the final edited version of the manuscript.

\section{ACKNOWLEDGMENTS}

Two Mexican research projects granted to SE, DGAPA (IN206710), and CONACYT (Conv-CB-2009: 129880), and an European project (PFP7-FORCE-244161) provided financial support to this research. This research was part of the $\mathrm{PhD}$ thesis of TS in the program Posgrado en Ciencias del Mar $y$ Limnología $(P C M y L)$ of the Universidad Nacional Autónoma de 
México (UNAM). The Consejo Nacional de Ciencia y Tecnología (CONACyT) is acknowledged for providing 3 years fellowship to support TS during his $\mathrm{PhD}$ program and the FORCE project is also acknowledged for providing 1 year fellowship to TS. The experiments performed in this work comply with the current laws of Mexico. An ethics approval was not required as per national regulations. The study was supported by two Mexican permits: "Permiso de Pesca de Fomento" No DGOPA.07342.010810.4121, to SE; and No DGOPA.08606.251011.3021, to RI; issued by the Secretaría de Agricultura, Ganadería, Desarrrollo rural, Pesca y Alimentación of the United States of Mexico, to support,

\section{REFERENCES}

Anthony, K. R. N., Hoogenboom, M. O., and Connolly, S. R. (2005). Adaptive variation in coral geometry and the optimization of internal colony light climates. Funct. Ecol. 19, 17-26. doi: 10.1111/j.0269-8463.2005.00925.x

Baker, A. C. (2004). "Symbiont diversity on coral reefs and its relationship to bleaching resistance and resilience," in Coral Health and Disease, eds E. Rosenberg and Y. Loya (Berlin: Springer Verlag), 177-194.

Barnes, D. J., and Lough, J. M. (1989). The Nature of skeletal density banding in scleractinian corals: fine banding and seasonal patterns. J. Exp. Mar. Biol. Ecol. 126, 119-134. doi: 10.1016/0022-0981(89)90084-1

Berkelmans, R., and van Oppen, M. J. H. (2006). The role of zooxanthellae in the thermal tolerance of corals: a "nugget of hope" for coral reefs in an era of climate change. Proc. R. Soc. Lond. B 272, 2305-2312. doi: 10.1098/rspb.2006.3567

Brodersen, K. E., Lichtenberg, M., Ralph, P. J., Kühl, M., and Wangpraseurt, D. (2014). Radiative energy budget reveals high photosynthetic efficiency in symbiont-bearing corals. J. R. Soc. Interface 11:20130997. doi: 10.1098/rsif.2013.0997

Brown, B. E., Dunne, R. P., Ambarsari, I., Le Tissier, M. D. A., and Satapoomin, U. (1999). Seasonal fluctuations in environmental factors and variations in symbiotic algae and chlorophyll pigments in four Indo-Pacific coral species. Mar. Ecol. Prog. Ser. 191, 53-69. doi: 10.3354/meps191053

Brown, B. E., Dunne, R. P., Goodson, M. S., and Douglas, A. E. (2000). Marine ecology: bleaching patterns in reef corals. Nature 404, 142-143. doi: $10.1038 / 35004657$

Budd, A. F., and Klaus, J. S. (2001). The origin and early evolution of the Montastraea "annularis" species complex (Anthozoa: Scleractinia)'. J. Paleontol. 75, 527-545. doi: 10.1017/S0022336000039640

Carter, G. A., and Knapp, A. K. (2001). Leaf optical properties in higher plants: linking spectral characteristics to stress and chlorophyll concentration. Am. J. Bot. 88, 677-684. doi: 10.2307/2657068

Cayabyab, N. M., and Enríquez, S. (2007). Leaf photoacclimatory responses of the tropical seagrass Thalassia testudinum under mesocosm conditions: a mechanistic scaling-up study. New Phytol. 176, 108-123. doi: 10.1111/j.1469-8137.2007.02147.x

Colombo-Pallotta, M. F., Rodríguez-Román, A., and Iglesias-Prieto, R. (2010). Calcification in bleached and unbleached Montastraea faveolata: evaluating the role of oxygen and glycerol. Coral Reefs 29, 899-907. doi: 10.1007/s00338-010-0638-x

Davis, P. A., Caylor, S., Whippo, C. W., and Hangarter, R. P. (2011). Changes in leaf optical properties associated with light-dependent chloroplast movement. Plant Cell Environ. 34, 2047-2059. doi: 10.1111/j.1365-3040.2011.02402.x

de Mendiburu, F. (2016). Agricolae: Statistical Procedures for Agricultural Research. $\mathrm{R}$ package version 1.2-4. Available online at: https:/CRAN.R-project.org/ package $=$ agricolae

Dubinsky, Z., Falkowski, P. G., Porter, J. W., and Muscatine, L. (1984). Absorption and utilization of radiant energy by light- and shade-adapted colonies of the hermatypic coral Stylophora pistillata. Proc. R. Soc. Lond. B 222:203-214. doi: 10.1098/rspb.1984.0059

Dubinsky, Z., Stambler, N., Ben-Zion, M., McCloskey, L., Muscatine, L., and Falkowski, P. G. (1990). The effect of external nutrient resources on the optical respectively, the development of the projects: "Evaluación del efecto de la limitación de carbono sobre diferentes productores primarios de la laguna arrecifal de Puerto Morelos: Importancia de la calcificación"; and "Efectos del calentamiento y acidificación del Océano en las tasas de calcificación de los corales."

\section{SUPPLEMENTARY MATERIAL}

The Supplementary Material for this article can be found online at: http://journal.frontiersin.org/article/10.3389/fmars. 2017.00309/full\#supplementary-material properties and photosynthetic efficiency of Stylophora pistillata. Proc. R. Soc. Lond. B 239, 231-246. doi: 10.1098/rspb.1990.0015

Duysens, L. N. (1956). The flattering of the absorption spectrum of suspensions, as compared to that of solutions'. Biochim. Biophys. Acta 19, 1-12. doi: 10.1016/0006-3002(56)90380-8

Enríquez, S. (2005). Light absorption efficiency and the package effect in the leaves of the seagrass Thalassia testudinum. Mar. Ecol. Prog. Ser. 289, 141-150. doi: 10.3354/meps289141

Enríquez, S., Agustí, S., and Duarte, C. M. (1994). Light absorption by marine macrophytes. Oecologia 98, 121-129. doi: 10.1007/BF00341462

Enríquez, S., and Sand-Jensen, K. (2003). Variation in light absorption properties of Mentha aquatica L. as a function of leaf form: implications for plant growth. Int. J. Plant Sci. 164, 125-136. doi: 10.1086/344759

Enríquez, S., Méndez, E. R., Hoegh-Guldberg, O., and Iglesias-Prieto, R. (2017). Key functional role of the optical properties of coral skeletons in coral ecology and evolution. Proc. R. Soc. Lond. B 284:20161667. doi: 10.1098/rspb.2016.1667

Enríquez, S., Méndez, E. R., and Iglesias-Prieto, R. (2005). Multiple scattering on coral skeletons enhances light absorption by symbiotic algae. Limnol. Oceanogr. 50, 1025-1032. doi: 10.4319/lo.2005.50.4.1025

Enríquez, S., Merino, M., and Iglesias-Prieto, R. (2002). Variation in the photosynthetic performance along the leaves of the tropical seagrass Thalassia testudinum. Mar. Biol. 140, 891-900. doi: 10.1007/s00227-001-0760-y

Fagoonee, I., Wilson, H. B., Hassell, M. P., and Turner, J. R. (1999). The dynamics of zooxanthellae populations: a long-term study in the field. Science 283, 843-845. doi: $10.1126 /$ science. 283.5403 .843

Falkowski, P. G., and Dubinsky, Z. (1981). Light-shade adaptation of Stylophora pistillata, a hermatypic coral from the Gulf of Eilat. Nature 289, 172-174. doi: $10.1038 / 289172 \mathrm{a} 0$

Ferrier-Pagès, C., Schoelzke, V., Jaubert, J., Muscatine, L., and HoeghGuldberg, O. (2001). Response of a scleractinian coral, Stylophora pistillata, to iron and nitrate enrichment. J. Exp. Mar. Biol. Ecol. 259, 249-261. doi: 10.1016/S0022-0981(01)00241-6

Fitt, W. K., McFarland, F. K., Warner, M. E., and Chilcoat, G. C. (2000). Seasonal patterns of tissue biomass and densities of symbiotic dinoflagellates in reef corals and relation to coral bleaching. Limnol. Oceanogr. 45, 677-685. doi: 10.4319/lo.2000.45.3.0677

Fitt, W. K., Gates, R. D., Hoegh-Guldberg, O., Bythell, J. C., Jatkar, A., Grottoli, A. G., et al. (2009). Response of two species of Indo-Pacific corals, Porites cylindrical and Stylophora pistillata, to short-term thermal stress: the host does matter in determining the tolerance of corals to bleaching. J. Exp. Mar. Biol. Ecol. 373, 102-110. doi: 10.1016/j.jembe.2009.03.011

Fox, J., and Weisberg, S. (2011). An R Companion to Applied Regression, 2nd Edn. Thousand Oaks CA: Sage.

Frost-Christensen, H., and Sand-Jensen, K. (1992). The quantum efficiency of photosynthesis in macroalgae and submerged angiosperms. Oecologia 91, 377-384. doi: 10.1007/BF00317627

Glynn, P. W. (1996). Coral reef bleaching: facts, hypotheses and implications. Glob. Change Biol. 2, 495-509. doi: 10.1111/j.1365-2486.1996.tb00063.x

Hennige, S. J., Suggett, D. J., Warner, M. E., McDougall, K. E., and Smith, D. J. (2009). Photobiology of Symbiodinium revisited: bio-physical and bio-optical signatures. Coral Reefs 28, 179-195. doi: 10.1007/s00338-008-0444-x 
Hoegh-Guldberg, O. (1999). Climate change, coral bleaching and the future of the world's coral reefs. Mar. Freshw. Res. 50, 839-866. doi: 10.1071/MF 99078

Hoegh-Guldberg, O., Fine, M., Skirving, W., Johnstone, R., Dove, S., and Strong, A. (2005). Coral bleaching following wintry weather. Limnol. Oceanogr. 50, 265-271. doi: 10.4319/lo.2005.50.1.0265

Iglesias-Prieto, R., and Trench, R. K. (1994). Acclimation and adaptation to irradiance in symbiotic dinoflagellates. I. Responses of the photosynthetic unit to changes in photon flux density. Mar. Ecol. Prog. Ser. 113, 163-175. doi: $10.3354 /$ meps 113163

Iglesias-Prieto, R., Matta, J. L., Robins, W. A., and Trench, R. K. (1992). Photosynthetic response to elevated temperature in the symbiotic dinoflagellate Symbiodinium microadriaticum in culture. Proc. Natl. Acad. Sci. U.S.A. 89, 10302-10305. doi: 10.1073/pnas.89.21.10302

Jeffrey, S. W., and Humphrey, G. F. (1975). New spectrophotometric equations for determining chlorophylls a, b, c1, and $\mathrm{c} 2$ in higher plants, algae, and natural phytoplankton. Biochem. Physiol. Pflanz. 167, 191-194. doi: 10.1016/S0015-3796(17)30778-3

Kemp, D. W., Cook, C. B., LaJeunesse, T. C., and Brooks, W. R. (2006). A comparison of the thermal bleaching responses of the zoanthid Palythoa caribaeorum from three geographically different regions in south Florida. J. Exp. Mar. Biol. Ecol. 335, 266-276. doi: 10.1016/j.jembe.2006.03.017

Kemp, D. W., Hernandez-Pech, X., Iglesias-Prieto, R., Fitt, W. K., and Schmidt, G. W. (2014). Community dynamics and physiology of Symbiodinium spp. before, during, and after a coral bleaching event. Limnol. Oceanogr. 59, 788-797. doi: 10.4319/lo.2014.59.3.0788

Kemp, D. W., Oakley, C. A., Thornhill, D. J., Newcomb, L. A., Schmidt, G. W., and Fitt, W. K. (2011). Catastrophic mortality on inshore coral reefs of the Florida Keys due to severe low-temperature stress. Glob. Change Biol. 17, 3468-3477. doi: 10.1111/j.1365-2486.2011.02487.x

Kemp, D. W., Thornhill, D. J., Rotjan, R. D., Iglesias-Prieto, R., Fitt, W. K., and Schmidt, G. W. (2015). Spatially distinct and regionally endemic Symbiodinium assemblages in the threatened Caribbean reef-building coral Orbicella faveolata. Coral Reefs 34, 535-547. doi: 10.1007/s00338-015-1277-z

Kirk, J. T. O. (2011). Light and Photosynthesis in Aquatic Ecosystems, 3rd Edn. New York, NY: Cambridge University Press.

Kühl, M., Cohen, Y., Dalsgraad, T., Jørgensen, B. B., and Revsbech, N. P. (1995). Mircoenvironment and photosynthesis of zooxanthellae in scleratinian corals studied with microsensors for O2, pH and light. Mar. Ecol. Prog. Ser. 117, 159-172. doi: 10.3354/meps117159

LaJeunesse, T. C. (2002). Diversity and community structure of symbiotic dinoflagellates from Caribbean coral reefs. Mar. Biol. 141, 387-400. doi: 10.1007/s00227-002-0829-2

Lesser, M. P., Mazel, C., Phinney, D., and Yentsch, C. S. (2000). Light absorption and utilization by colonies of the congeneric hermatypic corals Montastraea faveolata and Montastraea cavernosa. Limnol. Oceanogr. 45, 76-86. doi: 10.4319/lo.2000.45.1.0076

Lesser, M. P. (1996). Exposure of symbiotic dinoflagellates to elevated temperatures and ultraviolet radiation causes oxidative stress and photosynthesis. Limnol. Oceanogr. 41, 271-283. doi: 10.4319/lo.1996.41.2.0271

Lesser, M. P., and Farrell, J. (2004). Solar radiation increases the damage to both host tissues and algal symbionts of corals exposed to thermal stress. Coral Reefs 23, 367-377. doi: 10.1007/s00338-004-0392-Z

Madin, J. S., Hoogenboom, M. O., Connolly, S. R., Darling, E. S., Falster, D. S., Huang, D., et al. (2016). A trait-based approach to advance coral reef science. Trends Ecol. Evol. 31, 419-428. doi: 10.1016/j.tree.2016.02.012

Marcelino, L. A., Westneat, M. W., Stoyneva, V., Henss, J., Rogers, J. D., Radosevich, A., et al. (2013). Modulation of light-enhancement to symbiotic algae by light-scattering in corals and evolutionary trends in bleaching. PLoS ONE 8:e61492. doi: 10.1371/journal.pone.0061492

Marsh, J. A. (1970). Primary productivity of reef-building calcareous red algae. Ecology 51, 255-263. doi: 10.2307/1933661

Morel, A., and Bricaud, A. (1981). Theoretical results concerning light absorption in a discrete medium, and application to specific absorption of phytoplankton. Deep Sea Res. 28, 1375-1393. doi: 10.1016/0198-0149(81)90039-X

Muscatine, L., McCloskey, L. R., and Marian, R. E. (1981). Estimating the daily contribution of carbon from zooxanthellae to coral animal respiration. Limnol. Oceanogr. 26, 601-611. doi: 10.4319/lo.1981.26.4.0601
Pearse, V. B., and Muscatine, L. (1971). Role of symbiotic algae (zooxanthellae) in coral calcification. Bio. Bull. 141, 350-363. doi: 10.2307/1540123

Pettay, D. T., Wham, D. C., Smith, R. T., Iglesias-Prieto, R., and LaJeunesse, T. C. (2015). Microbial invasion of the Caribbean by an Indo-Pacific coral zooxanthella. Proc. Natl. Acad. Sci. U.S.A. 112, 7513-7518. doi: 10.1073/pnas.1502283112

R Core Team (2017). R: A Language and Environment for Statistical Computing. Vienna: R Foundation for Statistical Computing. Available online at: https:// www.R-project.org/

Robison, J. D., and Warner, M. E. (2006). Differential impacts of photoacclimation and thermal stress on the photobiology of four different phylotypes of Symbiodinium (Pyrrhophyta). J. Phycol. 42, 568-569. doi: 10.1111/j.1529-8817.2006.00232.x

Rodríguez-Román, A., Hernández-Pech, X., Tome, P. E., Enríquez, S., and IglesiasPrieto, R. (2006). Photosynthesis and light utilization in the Caribbean coral Montastraea faveolata recovering form a bleaching event. Limnol. Oceanogr. 51, 2702-2710. doi: 10.4319/lo.2006.51.6.2702

Savage, A. M., Trapido-Rosenthal, H., and Douglas, A. E. (2002). On the functional significance of molecular variation in Symbiodinium, the symbiotic algae of cnidarian: photosynthetic response to irradiance. Mar. Ecol. Prog. Ser. 244, 27-37. doi: 10.3354/meps244027

Scheufen, T., Krämer, W. E., Iglesias-Prieto, R., and Enríquez, S. (2017). Seasonal variation modulates coral sensibility to thermal-stress and explains annual changes in coral productivity. Sci. Rep. 7:4937. doi: 10.1038/s41598-017-04927-8

Shibata, K. (1969). Pigments and a UV-absorbing substance in corals and bluegreen alga living in the Great Barrier Reef. Plant Cell Physiol. 10, 325-335.

Smith, D. J., Suggett, D. J., and Baker, N. R. (2005). Is photoinhibition of zooxanthellae photosynthesis the primary cause of thermal bleaching in corals. Glob. Change Biol. 11, 1-11. doi: 10.1111/j.1529-8817.2003. 00895.X

Stambler, N., and Dubinsky, Z. (2005). Corals as light collectors: an integrating sphere approach. Coral Reefs 24, 1-9. doi: 10.1007/s00338-004-0452-4

Stimson, J., and Kinzie, I. I. I., R. A. (1991). The temporal pattern and rate of release of zooxanthellae from the reef coral Pocillopora damicornis (Linnaeus) under nitrogen-enrichment and control conditions. J. Exp. Mar. Biol. Ecol. 153, 63-74. doi: 10.1016/S0022-0981(05)80006-1

Stimson, J., Sakai, K., and Sembali, H. (2002). Interspecific comparison of the symbiotic relationship in corals with high and low rates of bleaching-induced mortality. Coral Reefs 21, 409-421. doi: 10.1007/s00338-002-0264-3

Suggett, D. J., Warner, M. E., Smith, D. J., Davey, P., Hennige, S., and Baker, N. R. (2008). Photosynthesis and production of hydrogen peroxide by Symbiodinium (pyrrhophyta) phylotypes with different thermal tolerances. J. Phycol. 44, 948-956. doi: 10.1111/j.1529-8817.2008.00537.x

Tchernov, D., Gorbunov, M. Y., de Vargas, C., Narayan Yadav, S., Milligan, A. J. Haggblom, M., et al. (2004). Membrane lipids of symbiotic algae are diagnostic of sensitivity to thermal bleaching in corals. Proc. Natl. Acad. Sci. U.S.A. 101, 13531-13535. doi: 10.1073/pnas.0402907101

Terán, E., Méndez, E. R., Enríquez, S., and Iglesias-Prieto, R. (2010). Multiple light scattering and absorption in reef-building corals. Appl. Opt. 49, 5032-5042. doi: 10.1364/AO.49.005032

Vásquez-Elizondo, R. M., Legaria-Moreno, L., Pérez-Castro, M. A., Krämer, W. E., Scheufen, T., Iglesias-Prieto, R., et al. (2017). Absorptance determinations in multicellular tissues. Photosynth. Res. 3, 311-324. doi: 10.1007/s11120-017-0395-6

Wangpraseurt, D., Jacques, S. L., Petrie, T., and Kühl, M. (2016). Monte carlo modeling of photon propagation reveals highly scattering coral tissue. Front. Plant Sci. 7:1404. doi: 10.3389/fpls.2016.01404

Wangpraseurt, D., Larkum, A. W., Franklin, J., Szabó, M., Ralph, P. J., and Kühl, M. (2014). Lateral light transfer ensures efficient resource distribution in symbiont-bearing corals. J. Exp. Biol. 217, 489-498. doi: 10.1242/jeb.0 91116

Wangpraseurt, D., Larkum, A. W., Ralph, P. J., and Kühl, M. (2012). Light gradients and optical microniches in coral tissues. Front. Microbiol. 3:316. doi: $10.3389 /$ fmicb. 2012.00316

Warner, M. E., LaJeunesse, T. C., Robison, J. D., and Thur, R. M. (2006). The ecological distribution and comparative photobiology of symbiotic dinoflagellates from reef corals in Belize: potential implications for 
coral bleaching. Limnol. Oceanogr. 51, 1887-1897. doi: 10.4319/lo.2006.51. 4.1887

Weis, V. M. (2008). Cellular mechanisms of Cnidarian bleaching: stress causes the collapse of symbiosis. J. Exp. Biol. 211, 3059-3066. doi: 10.1242/jeb.009597

Whitaker, J. R., and Granum, P. E. (1980). An absolute method for protein determination based on difference in absorbance at 235 and $280 \mathrm{~nm}$. Anal. Biochem. 109, 156-159. doi: 10.1016/0003-2697(80)90024-X

Wyman, K. D., Dubinsky, Z., Porter, J. W., and Falkowski, P. G. (1987). Light absorption and utilization among hermatypic corals: a study in Jamaica, West Indies. Mar. Biol. 96, 283-292. doi: 10.1007/BF00427028
Conflict of Interest Statement: The authors declare that the research was conducted in the absence of any commercial or financial relationships that could be construed as a potential conflict of interest.

Copyright (๑) 2017 Scheufen, Iglesias-Prieto and Enríquez. This is an open-access article distributed under the terms of the Creative Commons Attribution License (CC $B Y)$. The use, distribution or reproduction in other forums is permitted, provided the original author(s) or licensor are credited and that the original publication in this journal is cited, in accordance with accepted academic practice. No use, distribution or reproduction is permitted which does not comply with these terms. 